\title{
Foamy Viruses, Bet, and APOBEC3 Restriction
}

\author{
Ananda Ayyappan Jaguva Vasudevan ${ }^{1, *,+}$ (D), Daniel Becker ${ }^{2}$, Tom Luedde ${ }^{1}$, Holger Gohlke ${ }^{2,3}$ (D) \\ and Carsten Münk ${ }^{1, *}$
}

check for

updates

Citation: Jaguva Vasudevan, A.A.; Becker, D.; Luedde, T.; Gohlke, H.; Münk, C. Foamy Viruses, Bet, and APOBEC3 Restriction. Viruses 2021, 13, 504. https://doi.org/10.3390/ v13030504

Academic Editor: Linda Chelico

Received: 17 December 2020

Accepted: 16 March 2021

Published: 18 March 2021

Publisher's Note: MDPI stays neutral with regard to jurisdictional claims in published maps and institutional affiliations.
1 Clinic for Gastroenterology, Hepatology and Infectiology, Medical Faculty, Heinrich Heine University Düsseldorf, 40225 Düsseldorf, Germany; tom.luedde@med.uni-duesseldorf.de

2 Institute for Pharmaceutical and Medicinal Chemistry, Heinrich Heine University Düsseldorf, 40225 Düsseldorf, Germany; d.becker@uni-duesseldorf.de (D.B.); gohlke@uni-duesseldorf.de (H.G.)

3 John von Neumann Institute for Computing (NIC), Jülich Supercomputing Centre \& Institute of Biological Information Processing (IBI-7: Structural Biochemistry), Forschungszentrum Jülich GmbH, 52425 Jülich, Germany

* Correspondence: anand.jaguvavasudevan@nih.gov (A.A.J.V.); carsten.muenk@med.uni-duesseldorf.de (C.M.); Tel.: +49-(0)-211-81-10887 (C.M.)

$+\quad$ Present address: Structural Cell Biology Group, Genome Integrity and Structural Biology Laboratory, National Institute of Environmental Health Sciences (NIEHS), NIH, Research Triangle Park, NC 27709, USA.

\begin{abstract}
Non-human primates (NHP) are an important source of viruses that can spillover to humans and, after adaptation, spread through the host population. Whereas HIV-1 and HTLV-1 emerged as retroviral pathogens in humans, a unique class of retroviruses called foamy viruses (FV) with zoonotic potential are occasionally detected in bushmeat hunters or zookeepers. Various FVs are endemic in numerous mammalian natural hosts, such as primates, felines, bovines, and equines, and other animals, but not in humans. They are apathogenic, and significant differences exist between the viral life cycles of FV and other retroviruses. Importantly, FVs replicate in the presence of many well-defined retroviral restriction factors such as TRIM5 $\alpha$, BST2 (Tetherin), MX2, and APOBEC3 (A3). While the interaction of A3s with HIV-1 is well studied, the escape mechanisms of FVs from restriction by $\mathrm{A} 3$ is much less explored. Here we review the current knowledge of FV biology, host restriction factors, and FV-host interactions with an emphasis on the consequences of FV regulatory protein Bet binding to A3s and outline crucial open questions for future studies.
\end{abstract}

Keywords: foamy virus; retrovirus; Bet; APOBEC3; cytidine deaminase; restriction factors; mutation; viral restriction; viral antagonist

\section{Foamy Viruses}

The first description of a foamy virus (FV) was reported in 1954 [1]. It was found as a contaminant with an atypical cytopathic effect (CPE), eliciting the formation of multinucleated and vacuolated giant cells in primary kidney cell cultures from Old World monkeys of the Macacaceae family. The name FV or spumaretrovirus was derived from the foam-like appearance of syncytia in the infected monolayer cell cultures. FVs were classified as retroviruses after the detection of the FV reverse transcription (RT) enzyme. The first isolation of the "foamy viral agent" occurred in 1955 [2]. In 1971, a viral agent with FV-like characteristics was identified from lymphoblastoid cells in cultures of a nasopharyngeal carcinoma (NPC) from a Kenyan patient [3]. The origin of this human foamy virus (HFV) was discussed until 1994, when HFV was cloned and sequenced [4]. The 86 to 95\% amino acid identity between simian foamy virus from chimpanzee (SFVcpz) and HFV suggested that HFV is likely a variant of SFVcpz and not a unique isolate [4]. Sequence comparisons between the original HFV isolate and SFV from four distinct subspecies of chimpanzee demonstrate that it is most closely related to FV from Pan troglodytes schweinfurthii, whose natural habitat includes Kenya. Since the original HFV isolate came from a person who might have had contact with chimpanzees in Kenya, the virus was probably acquired as a 
zoonotic infection (transmission from animals to humans). For detailed reviews on foamy virus epidemiology and zoonotic infections see [5-7]. HFV has now been renamed as the prototype foamy virus (PFV), although it is debated whether the "real" origin of the virus isolate derived from in vivo cross-species transmission from chimpanzee or from a cell culture contamination [5]. Evidence suggests that diverse SFVs are transmitted from primates to humans, but not between humans [5,8-12]. Notably, African green monkeys and apes have a higher prevalence for SFV, and then for simian immunodeficiency virus (SIV), and SIV-infected animals are often also positive for SFVs, indicating that co-infection of these two viruses is common in African primates [13-18].

\section{Host-Virus Co-Speciation and Evolution}

\subsection{Simian Foamy Viruses}

FV genomes display high evolutionary conservation among all the species infected, and FV genetic variability within one infected animal is very low over time ( $<1 \%$ variation) [19]. The phylogenetic analysis of SFV polymerase and mitochondrial cytochrome oxidase subunit II (COII) from African and Asian primates provide very similar branching order and divergence times among the two trees, supporting the co-speciation. Molecular clock calibrations have revealed an extremely low rate of SFV evolution, $1.7 \times 10^{-8}$ base substitutions per site per year, making FV the slowest-evolving virus documented so far. These investigations moreover revealed highly congruent relationships, indicating virus-host co-evolution for at least 30-40 million years [20,21]. The various SFVs do not seem to cause any recognizable disease in their natural hosts, despite being highly cytopathic in tissue culture $[5,6,22,23]$. Although copying of the FV genome is highly accurate, therefore maintaining a stable genome, frequent recombination events between several circulating FV strains, as well as deletions and mutations, have been reported in wild-living chimpanzees [14,24].

SFVs are highly prevalent. In captive primate populations, infection rates ranging from $70 \%$ to $100 \%$ are reported in adult animals $[5,6,23]$, and similarly high numbers of SFVcpz infections in wild-living chimpanzees across equatorial Africa were documented [14]. High FV prevalence was also reported in the Asian macaques (Macaca fascicularis) population and Wild red colobus monkeys in Tai national park, West Africa [11,25] as well as in New World primates in Central and South America [26]. A recent study identified a diversity of SFV strains in free-ranging rhesus macaques in Bangladesh [27]. Adult chimpanzees had significantly higher infection rates (13 out of 13 animals) than infants and juveniles, suggesting horizontal transmission [14]. Hunters, poachers, zookeepers, temple workers, and villagers who are occupationally exposed to non-human primates (NHP) can also become infected with SFV [28-31] (documented in [5]). Ongoing zoonotic transmissions are reported from zoos or primate centers in Gabon and in China [32-34], and also confirmed in hunters in Gabon, where severe bites from gorillas were causative [34]. However, humans are dead-end hosts of primate foamy viruses, and no human foamy virus has evolved so far $[10,35,36]$.

\subsection{Non-Simian Foamy Viruses}

FVs are also prevalent in non-simian hosts such as cats [37,38], pumas [39], cattle [40-42], horses [43], certain bats (Rhinolophus affinis) [44], and likely more species (reviewed in [15,45-47]). Apparently, these FVs are non-pathogenic in their hosts, and the infection prevalence is recorded as about $7-45 \%$ in cattle and $30-100 \%$ in cats, mainly in adults [45,47-50]. Isolation of an equine FV and a comprehensive sero-epidemiology of infections were reported recently, with a positive rate of $25-41 \%$ [51]. These reports suggest that non-simian FV infections are highly prevalent in these animals. 


\subsection{Endogenous Foamy Viruses}

When retroviruses get access to gametocytes, the resulting endogenous provirus can be passaged in the germline along with the host cell genome, but in most cases carries inactivating mutations or deletions [52,53]. Endogenous FVs were discovered in the genomes of the Madagascar aye-aye (Daubentonia madagascariensis, a strepsirrhine primate), the twotoed (Choloepus hoffmanni) and three-toed sloths (Bradypus pygmaeus) from South America, platyfish (Xiphophorus maculatus), and cod species [54-56], and FV-like insertions within the genome of the Coelacanth (Latimeria chalumnae) [57]. Very recently, 36 novel lineages of amphibian and fish foamy-like endogenous retroviruses were identified, and the ancient marine origin of retroviruses was suggested to be in the Ordovician period, early Palaeozoic Era, coinciding with the origin of jawed vertebrates [58]. Recent studies also identified endogenous FV sequences in genomes of reptiles, birds, and snakes [59-62]. Together, these results provide details of FV-host coevolution over a time of over 450 million years (MYA). These findings of newly identified ancient endogenous and an increasing number of exogenous FVs not only extend the age of FVs, but the finding in non-mammalian vertebrate phyla supports the concept of the great evolutionary success of this retroviral subfamily [63].

\section{Molecular Biology of FV}

Foamy viruses have complex RNA genomes (ranging from $10.5 \mathrm{kbp}$ Feline FV [64] to $13 \mathrm{kbp}$ SFVcpz [4]), which encode Tas (or bel-1) (a nuclear transcriptional transactivator) and Bet (an auxiliary protein) in addition to Gag, Pol, and Env. Of note, the Bet protein of $\mathrm{FV}$ is not related to "bromodomain and extra-terminal (BET) proteins", which are cellular histone acetylation readers.

FVs display several peculiar features among retroviruses. FV Gag is translated as a precursor protein only as Gag and not also as a Gag-Pol fusion protein [65-67]. FV Gag lacks characteristic domains such as membrane-binding domains, the major homology regions (MHR), and the hallmark Cys-His motifs. Rather, they possess numerous specific domains, such as the essential Gag-Env interaction domain and the Gly and Arg rich boxes (GR) regions, reviewed in [68]. Moreover, FV Gag undergoes limited maturation by the FV protease. This processing of Gag (PFV pr71 Gag) does not yield matrix, capsid, and nucleocapsid (so FVs have an "immature" appearance, despite being highly infectious), but only removes a small $3 \mathrm{kDa}$ C-terminal peptide resulting in p68 Gag $[69,70]$, which is essential for FV infectivity [71,72].

Unlike Pol proteins from orthoretrovirinae, FV Pol is synthesized independently of Gag (from a singly spliced pol mRNA), and encapsidation of Pol is thought to be mediated by viral RNA bridging Gag and Pol molecules [73-76]. The fidelity of PFV PR-RT with respect to base substitutions was suggested to be similar to that of HIV-1 RT, although it can generate more insertions and deletions [77]. In comparison with the DNA polymerase processivity of HIV-RT, the processivity of PFV PR-RT is higher; therefore, having a few Pol molecules in the viral particles might be sufficient for productive infection [77-80]. In contrast to the orthoretroviruses, FV reverse transcription takes place to some extent $(5-10 \%)$ late in the infection cycle (before the virus leaves the cell) $[67,81,82]$. During virus assembly, the pregenomic ssRNA (as a dimer) is incorporated and can be reverse transcribed to dsDNA before virus release (Figure 1). While it is generally accepted that viral genomic DNA contributes to productive infection during the spreading of FVs in cultures, both viral genomic RNA- and DNA-containing particles are found in the supernatant of FV-infected cells. Furthermore, studies conducted with reverse transcriptase inhibitor AZT ( $3^{\prime}$-azido- $3^{\prime}$ deoxythymidine) indicate that reverse transcription is mostly complete prior to an extracellular virus infecting new cells $[67,76,81,83-86]$. A few studies supported the existence of an early RT step during foamy virus infection upon entry, which is thought to be relevant at low multiplicities of infection [82,87]. The biological relevance of virions with DNA or RNA genomes is controversially discussed, and the precise proportion of these needs to be determined, especially in vivo $[14,67,81,82,86-88]$. 


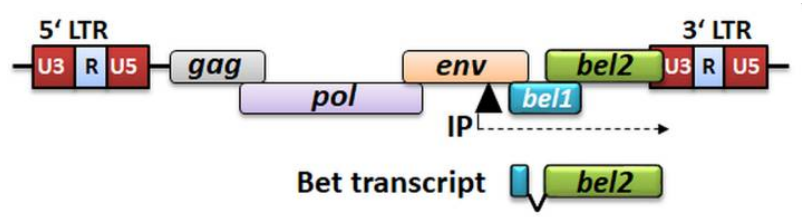

(A)

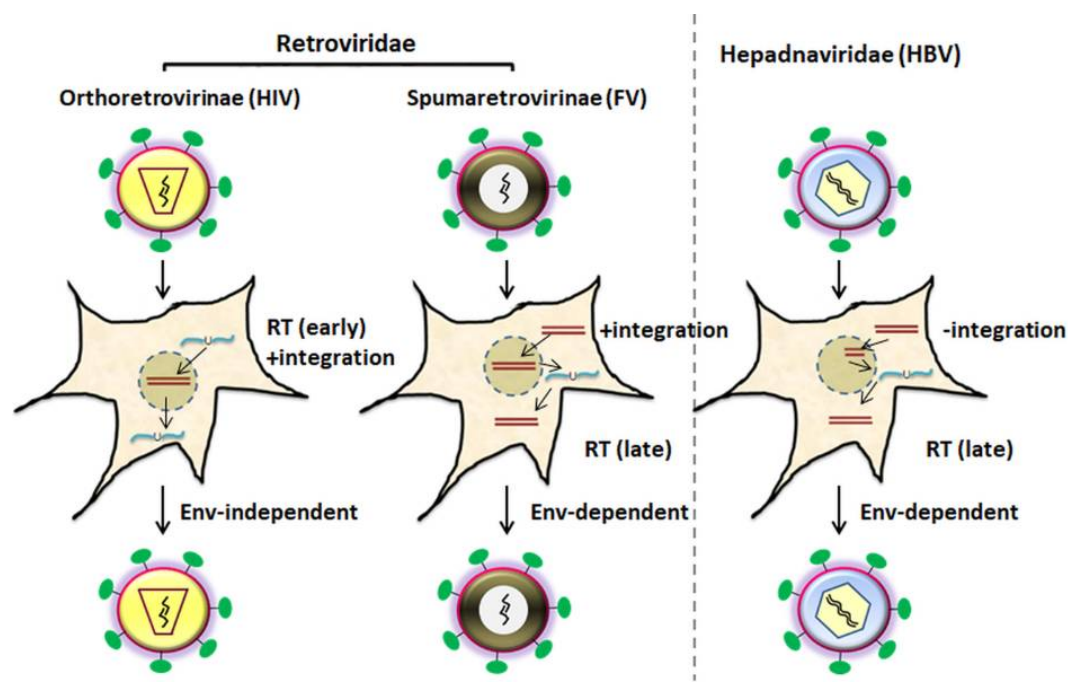

(B)

Figure 1. Genome organization of foamy viruses (FV) and schematic representation of replication strategies of animal viruses using reverse transcription (RT). (A) FV possesses gag, pol, and env genes. Additional regulatory and accessory bel1 and bel2 genes are localized between env and the $3^{\prime}$ LTR The Bet protein is a product of a spliced transcript and consists of Bel1 (also known as Tas) and Bel2 (alternatively called ORF2) parts. Bel1 and bel2 transcripts are originating from the internal promoter (IP) element, which is indicated as a black triangle, and the direction of transcription is marked with a dashed arrow (figure modified from [89]). (B) Replication cycle: Orthoretroviruses (RNA genome in the virion) such as HIV-1 replicate through a dsDNA intermediate and require integration of viral genome into host genome for propagation. Hepadnaviruses (dsDNA in the virion) instead do not integrate their genome but require an RNA intermediate (late RT) for their replication. FVs integrate their genome (DNA) into the host chromosomal DNA like orthoretroviruses, but undergo late reverse transcription like hepadnaviruses. It is controversially discussed in the literature that FV virus particles encapsidate genomic viral RNA or already reverse-transcribed DNA, and the exact copy numbers of both viral genomic RNA and DNA in "cell-free" FV particles remains to be determined in vivo $[14,67,82,86,87,90]$. The release of FV viral particles depends on the FV glycoprotein [91] as in hepadnaviruses, while budding of orthoretroviral particles is Env-independent. RT, reverse transcriptase, RNA and DNA molecules are denoted by blue lines with $U$ and brown lines respectively. Arrows in the figure indicate the path of the viral replication event. (Figure adapted from [63] and taken from one author's thesis [92]). Hepadnaviruses are depicted here to illustrate different viral replication strategies of animal viruses with a reverse transcription step.

FVs are unable to establish a productive infection in G1/S growth-arrested or nondividing cells [93], requiring mitosis for proviral integration and gene expression [93-96]. In vitro, FVs have the capacity to infect most cell types of vertebrate origin from fish to humans $[45,97,98]$. Heparan sulfate proteoglycans are suggested as an attachment factor for FV entry $[99,100]$. Glycoprotein-dependent FV entry into the host cells is achieved by $\mathrm{pH}$-dependent endocytosis and, alternatively, the release of naked FV capsids (cores) into the cytoplasm after fusion with the plasma membrane. Viral cores are then shuttled along microtubules and accumulate at the microtubule organizing center (MTOC). Uncoating 
of capsids assisted by the host and viral proteases occurs during mitosis, and ultimately, the preintegration complex (PIC) gets access to the chromatin (via Gag tethering) for the viral genome integration [101-104], reviewed in [105,106]. Whereas studies on FV cellular tropism in vivo are very limited, some reports indicated that FV DNA was detected in CD4+ and CD8+ lymphocytes, monocytes, and B-cells in humans, African green monkeys (AGM), chimpanzee, gorilla, and cattle [10,107-110]. One study suggested that the niche of in vivo FV replication in primates is limited to the differentiated superficial epithelial cells of the oral mucosa, a short-lived reservoir, resulting in nonpathogenic infections [111].

\section{Innate Immune Sensing of Foamy Viruses}

Like other viruses, FVs not only have to exploit various host machinery for their productive replication, but they have also to escape or counteract host antiviral responses, such as innate immune sensing and inhibition by cellular restriction factors. This area of research is particularly interesting because FV infections are apparently apathogenic in the hosts, but in vitro, FV infection triggers cytopathic effects and ultimately leads to cell death [22]. However, recent case-control studies among Cameroonian hunters infected with gorilla SFV identified an association of T-cell differentiation, monocyte activation, and hematological abnormalities with SFV infection $[112,113]$. These and a similar study that characterized an association of FFV with chronic kidney disease in cats [114] suggest that more research is needed to explore in vivo pathological changes by FVs.

Innate sensing of FV is not well characterized. Early studies suggested a lack of type I interferon (IFN-I) induction by simian and human FV infections in different cell lines [115-117]. However, a later study demonstrated that FVs are sensed by human hematopoietic cells such as PBMCs and pDCs potently inducing the production of IFN-I and associated IFN-stimulated genes (ISG), like MX1 [118]. This study further highlighted that RNA but not DNA is responsible for the trigger, and TLR7 was identified as the main sensor. In cell culture, treatment with IFNs led to viral inhibition [116,117,119-123]. Our own results also supported the inhibition of various FVs by IFN- $\beta$, but not by the ISG product MX2 [124]. Additionally, a new study suggested that pharmacological inhibitors of the IFN-I response enhance the replication of primary gorilla SFVs [125]. Very recently, using a myeloid cell model, the innate sensing pathways involved in FV infection were described [88]. Efficient ISG induction was demonstrated by sensing of full-length PFV genomes but not of minimal vectors in the cytoplasm. Moreover, this study suggested that viral DNA but not RNA acts as the key stimulator since this innate response was mainly dependent on cellular cGAS and STING, and unaffected by RT inhibition during entry [88]. Foamy viral escape from sensing may be mediated in PFV infections by Gag-induced endosomal autophagy that facilitates the clearance of stress granules to repress an IFN-I response of the infected cell [126]. In addition, FV encoded micro-RNAs (miRNAs) as shown in BFV [127] and SFVs [128] could act as regulators of the innate immune response. BFV miR-BF2-5p can suppress the expression of IFN- $\beta$ and NF-kB mRNAs by targeting Ankyrin Repeat Domain 17 (ANKRD17), an upstream regulator in the innate immune system and Bax-interacting factor 1 (Bif-1, official name SH3GLB1) [129].

\section{Foamy Virus Inhibition by Cellular Restriction Factors}

Specific IFN-induced cellular gene products are able to restrict different retroviruses, including FVs [121,122,130-142]. Similar to other retroviruses, TRIM5 $\alpha$ targets the core of PFV, SFV, and FFV during early post-infection events in a species-dependent manner $[135,139,143]$. The broad-spectrum of retroviral particle release inhibition by BST2 (tetherin) was reported to include FVs $[131,132,137]$. Fv1, a rodent restriction factor that inhibits murine leukemia virus (MLV), specifically, the Fv1 from Mus caroli, was found to inhibit FFV [138,144]. Human interferon-induced $35 \mathrm{kDa}$ protein (IFP35), an interferon-induced leucine zipper protein, was reported to confer resistance to BFV and PFV infection by inhibiting Tas of BFV and PFV [142]. Furthermore, proteasomal-dependent degradation of PFV Tas by an E3 ubiquitin ligase, human p53-induced RING-H2 protein (PIRH2, official name RCHY1), was identi- 
fied. PIRH2 was demonstrated to inhibit PFV replication and decreased the Tas-dependent transcriptional activation of the viral LTR and internal (IP) promoter [145]. A recent study using a screen of ISGs identified PHD finger domain protein-1 (PHF11) as an additional inhibitor of PFV [133]. Interestingly, PHF11 from humans and macaques were reported to be antiviral against multiple FVs but to be inactive against orthoretroviruses; thus, it appears to be FV-specific. PHF11 targets basal Tas expression by the IP (Figure 1A). As a consequence, Tas-dependent LTR activation is prevented, likely promoting viral latency [133]. Moreover, human/bovine N-Myc interactors (NMI) [146] and human interferon-induced transmembrane (IFITM) proteins [141] were identified to restrict PFV/BFV and FFV replication, respectively [141].

Another type of innate frontline defense against retroviruses is mediated by the members of the APOBEC3 (A3) cytidine deaminases family. Our earlier study reported the DNA editing of the FFV genome in A3-positive feline CRFK cells (non-permissive phenotype), which dramatically diminished the FFV titer [134]. Two other studies demonstrated A3mediated (A3C, A3G, A3F from human, mA3, and cpzA3G) inhibition of PFV infectivity, correlating with encapsidation of A3 into PFV vectors due to a specific Gag-A3 interaction and cytidine deamination of the viral reverse transcripts that resulted in G-to-A hypermutation of the viral genome. Of note, both studies used PFV-based single-round replication vectors $[130,136]$. Using a new statistical approach, A3G-mediated G-to-A hypermutation was detected and quantified in macaques and humans who were zoonotically infected. These data suggest that human A3G but not simian A3s induce hypermutations, which are lethal to the virus, hence protecting humans from SFV transmission [27,147]. The following chapters discuss briefly A3 proteins, and then focus on Bet protein and A3s-FV interactions. The important role of the Bet protein in counteracting A3s and various Bet-A3 interactions that lead to the escape of FVs are highlighted.

\section{APOBEC3s: Eutheria-Specific Antiviral Polynucleotide DNA Cytidine Deaminases}

The apolipoprotein B mRNA-editing enzyme, catalytic polypeptide-like 3 (APOBEC3, A3) family of single-stranded (ss) DNA cytidine deaminases provides mammals with an innate immune barrier against retroviruses, retrotransposons, and other viral pathogens [148-153]. All placental mammals encode at least one A3 gene. Whereas rodents possess single A3 (mouse $A 3, m A 3$ for instance) genes, humans express seven $\mathrm{A} 3$ proteins, and bats likely up to 18 distinct $A 3$ s from as many genes $[149,154-156]$. The A3 proteins have either one or two zinc-coordinating DNA cytidine deaminase domains (Z). Human A3A, A3C, and $\mathrm{A} 3 \mathrm{H}$ possess one and human $\mathrm{A} 3 \mathrm{~B}, \mathrm{~A} 3 \mathrm{D}, \mathrm{A} 3 \mathrm{~F}$, and $\mathrm{A} 3 \mathrm{G}$ two Z-domains, respectively, but only one $\mathrm{Z}$ domain is catalytically active in each A3 [148,149,157,158].

The domain structure of $A 3$ s consists of a conserved sequence of characteristic motifs ( $\left.\alpha 1-\beta 1-\beta 2 / 2^{\prime}-\alpha 2-\beta 3-\alpha 3-\beta 4-\alpha 4-\beta 5-\alpha 5-\alpha 6\right)$ [151,152]. At first A3G, then A3F, and other A3s were described as restriction factors because of their ability to inhibit the replication of Vif-deficient HIV-1 [150,151,153,159,160]. Based on the prevailing model of retrovirus restriction, A3s interact with viral components such as capsid, nucleocapsid, and nucleic acids to become encapsidated into nascent virions. Upon infection of target cells, the passenger $\mathrm{A} 3 \mathrm{~s}$ in the viral core deaminate the negative strand $\mathrm{cDNA}$ formed during reverse transcription of the viral RNA. A3s induce hypermutation (C-to-T deamination) on this single-stranded DNA, thereby editing the coding viral DNA strand ( $\rightarrow A$ ), leading to the inhibition of productive viral infection. Additional modes of inhibition of retroviruses are also well established that are not dependent on deaminase activity [161-163]. Based on cell-type and tissue, A3 expression is constitutive or inducible (e.g., by interferons). In general, A3s are expressed widely in hematopoietic cells [164-168].

During infection by lentiviruses (a group of retroviruses that includes HIV-1) the antiviral activity of the host-species' A3 is counteracted by the viral Vif protein. Vif directly binds to $\mathrm{A} 3$ and recruits an $\mathrm{E} 3$ ubiquitin ligase complex for polyubiquitination and proteasomal degradation of A3 [169-173]. This leads to intracellular depletion of $\mathrm{A} 3 \mathrm{~s}$ and allows the production of infectious viral particles that are mostly devoid of A3s. 
In addition, degradation-independent mechanisms such as Vif-mediated inhibition of A3G translation and A3G deaminase activity are also known [174-178]. Furthermore, retroviruses that lack a functional Vif-like gene have evolved different viral proteins and alternative countermeasures to prevent the antiviral activity of A3s. For instance, murine leukemia virus (MLV) glycoGag (a glycosylated translation product of the gag gene that is initiated by an upstream CUG codon (p80)), can antagonize $\mathrm{mA} 3$ and certain human A3s' restriction activity $[168,179-182]$. GlycoGag protects MLV by providing sufficient stability to viral cores, thereby hindering $\mathrm{mA} 3$ access to the MLV-RT complex in target cells. GlycoGag was shown to protect the genomes of some MLV strains from mA3 deamination; however, the precise mechanism of this protection remains to be elucidated (reviewed in [162]). Along the same lines, the Bet accessory protein from several FVs was demonstrated to sequester A3s in a degradation-independent manner [134,136,183-185].

\section{FV Auxiliary Protein Bet}

FVs encode two non-structural proteins, Tas and Bet, which are implicated in overcoming host innate immunity. Whereas the transcriptional activator function of Tas and its role in inhibiting RNA silencing pathways have been known for some time [186], a dedicated function of Bet was not described until recently. The FV accessory protein Bet is a unique protein with no similarities to other viral or cellular proteins [187]. Presumably, Bet is highly expressed in infected primates, cats, and cows, since antibodies against Bet and Bet expression are constantly detectable and are considered to be of diagnostic value $[49,108,188,189]$. Bet is likely a phosphoprotein [188], but the modified residues and potential kinases are unknown. Bet is found in vast amounts in the cytoplasm of infected or transfected cells [190,191], and it may localize to the nucleus by its C-terminal NLS [192]. Bet may also be secreted via unconventional exocytosis (not dependent on ER-to-Golgi secretory pathway) and enter uninfected cells [192]. While Bet is not required for FV infection in vitro in most assays [193-196], it has been proposed to regulate viral latency $[192,197,198]$, establishing infection and maintaining persistence [199], to be involved in resistance to viral superinfection [200], and Bet of bovine FV (BFV) was characterized as a negative regulator of BFV replication [201]. In addition, FFV Bet is essential for infectivity and appears to have a role in viral particle release [202]. Evidence for an essential function independent of inhibiting antiviral A3 proteins was obtained by in vivo infections of FFV that expressed the feline immunodeficiency virus (FIV) Vif protein instead of Bet [203]. Such chimeric viruses replicated in feline A3-expressing cells, but were attenuated in vivo in cats.

\section{Structure and Function Prediction of Bet}

The extent of protein sequence homology of Bet is low among FVs [43,48,89]. The Bet proteins from PFV, SFVs, and FFV are rather diverse and share only $6.7 \%$ of amino acid identity and $64 \%$ of similarity. PFV and SFV Bet proteins from chimpanzee and macaque have a higher identity and similarity, i.e., $32 \%$ and $79 \%$, respectively (Figure 2).

Despite recent advances in ab initio protein structure prediction [205], template-based structure modeling is still considered to yield high-quality structural models if appropriate template structures can be identified [206]. However, using the full-length sequences of the PFV, SFV-macaque, SFV-chimpanzee, and FFV Bet proteins, none of the template-based methods TopModel [206-209], I-TASSER [210-212], Maestro Homology Modelling [213], or SWISS-MODEL [214,215] yielded structural models of sufficient quality. This is probably due to the lack of templates with a high enough sequence identity; e.g., the best template found by I-TASSER for the SFV-chimpanzee Bet protein was 2OCW_A, with an identity of $12.4 \%$. Predicting structural models $a b$ initio based on the full sequences with ROSETTA3 [216] or the ROBETTA webserver [217] did not yield results of sufficient quality either. Finally, modeling the full-length sequences with constraints from coevolutionary information is not possible either because the GREMLIN webserver [218-220] or Blast [221] 
searches did not identify enough homologous sequences for reliably detecting residues that coevolved.

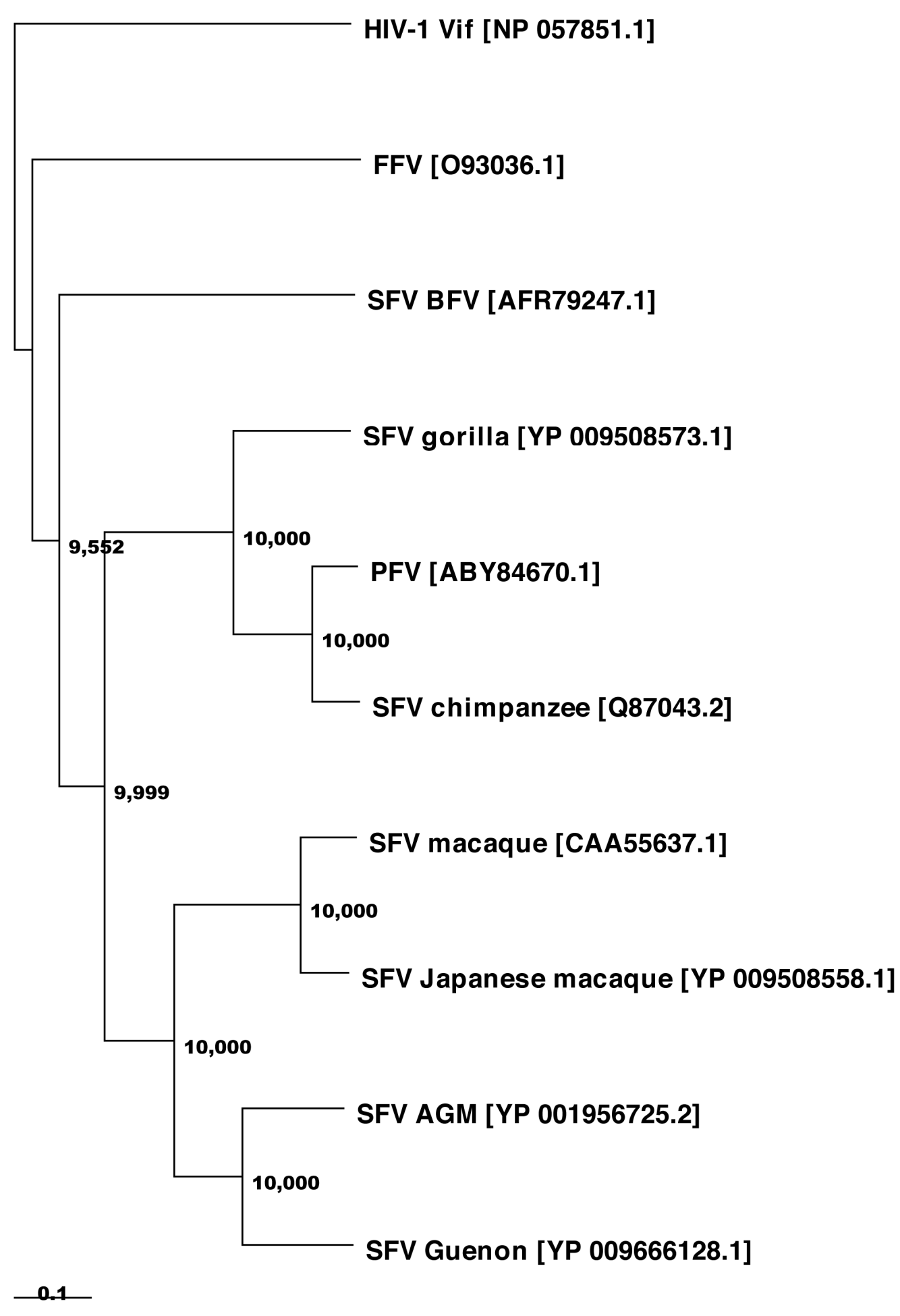

(A)

Figure 2. Cont. 


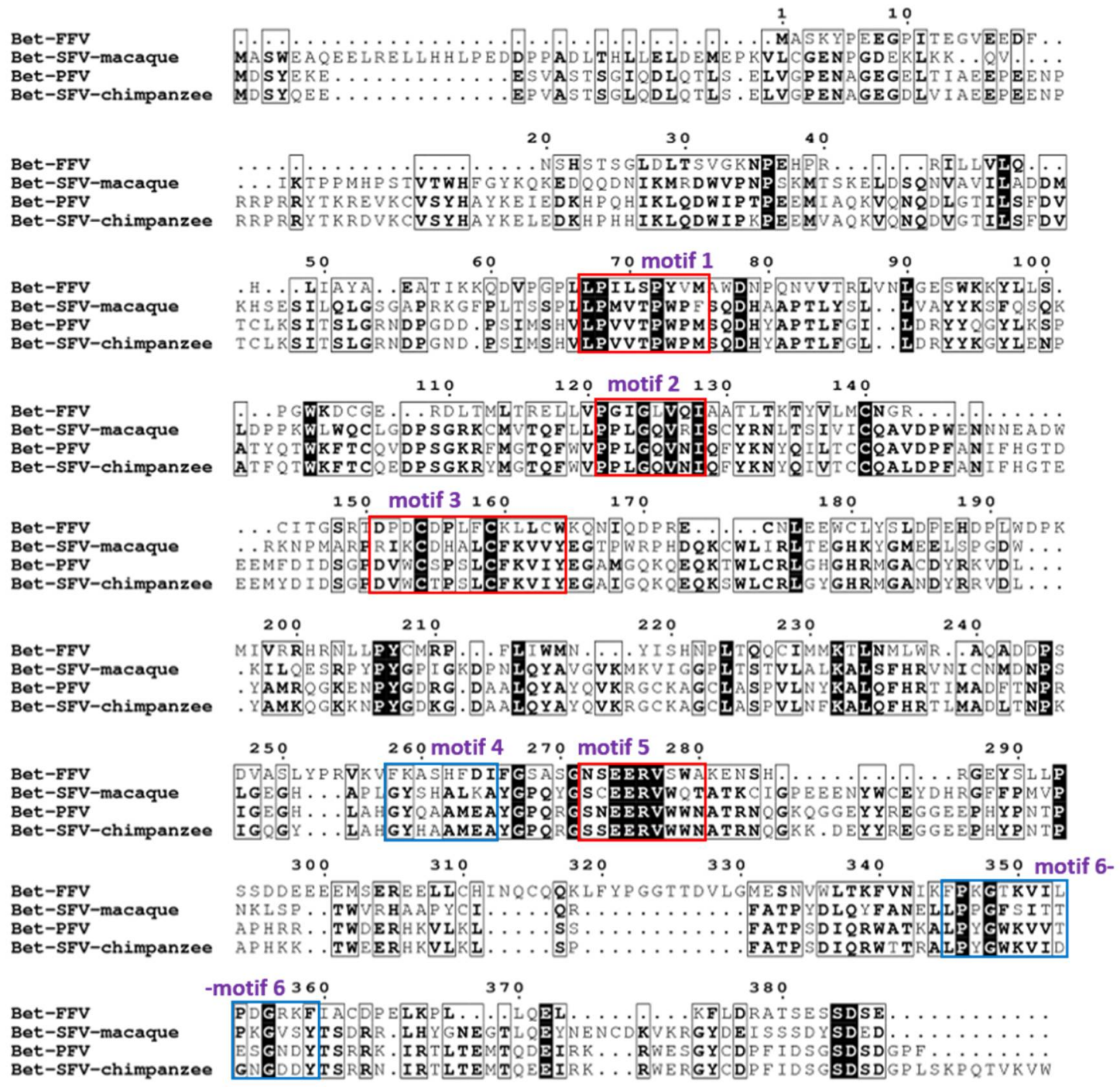

(B)

Figure 2. The diversity of Bet proteins. (A) Phylogeny of FV Bet amino acid sequences. A neighbor-joining tree based on Bet protein sequences was calculated by using the Maximum Composite Likelihood method with a bootstrap test of 10,000 replicates. Bet from BFV, FFV, SFVs (from gorilla, chimpanzee, macaque, Japanese macaque, AGM, and Guenon); HIV-1 Vif served as the out-group. Bar, 10\% sequence variation. Accession numbers are provided for each sequence in the bracket. Note that we could not include Bet from other exogenous and endogenous FVs due to the lack of sequence description. (B) Multiple sequence alignment of Bet from FFV, PFV, and SFVs. Amino acid sequence identity and similarity among these Bet proteins are $6.7 \%$ and $64 \%$, respectively. Additional sequence alignment leaving FFV Bet exhibited $32 \%$ identity and $79 \%$ similarity of primate FV Bet sequence (alignment not shown). Sequence alignment was performed by Clustal Omega (http:/ / www.ebi.ac.uk/Tools/msa/clustalo/, accessed on 6 December 2020). The alignment file was then submitted to ESPript 3.0 [204] (espript.ibcp.fr) to calculate the similarity and identity of residues between these proteins and to represent the multiple sequence alignment. Six conserved motifs in Bet sequences are marked by boxes, from which four red-colored motifs were experimentally studied due to high sequence conservation, as reported before [89].

Therefore, we decided to predict domain boundaries within the sequence of the SFVchimpanzee Bet protein sequence with TopDomain [222] (Figure 3A) and subsequently modeled the two domains using the ROBETTA webserver. For each domain, ROBETTA generated five models. The best model (Figure 3B) was then chosen based on the lowest $\mathrm{C}_{\alpha}$ atom RMSD between the generated models and the corresponding ab initio modeled domain of PFV Bet. This consensus approach was also validated by TopScore [223] in that domains with the lowest RMSD also have the lowest TopScore compared to the other 
four models. For the N-terminal domain, the overall TopScore is 0.47 and for the C-terminal one 0.45 , indicating a moderate quality of the models. In the N-terminal domain, the helical part of the structure has low local TopScores, indicating good quality, but the N-terminal loops high local TopScores, indicating low quality. In the C-terminal domain, the $\beta$-strands have low local TopScores, indicating good quality, but helices and loops from residues 358-403 have high local TopScores, indicating low quality.

A
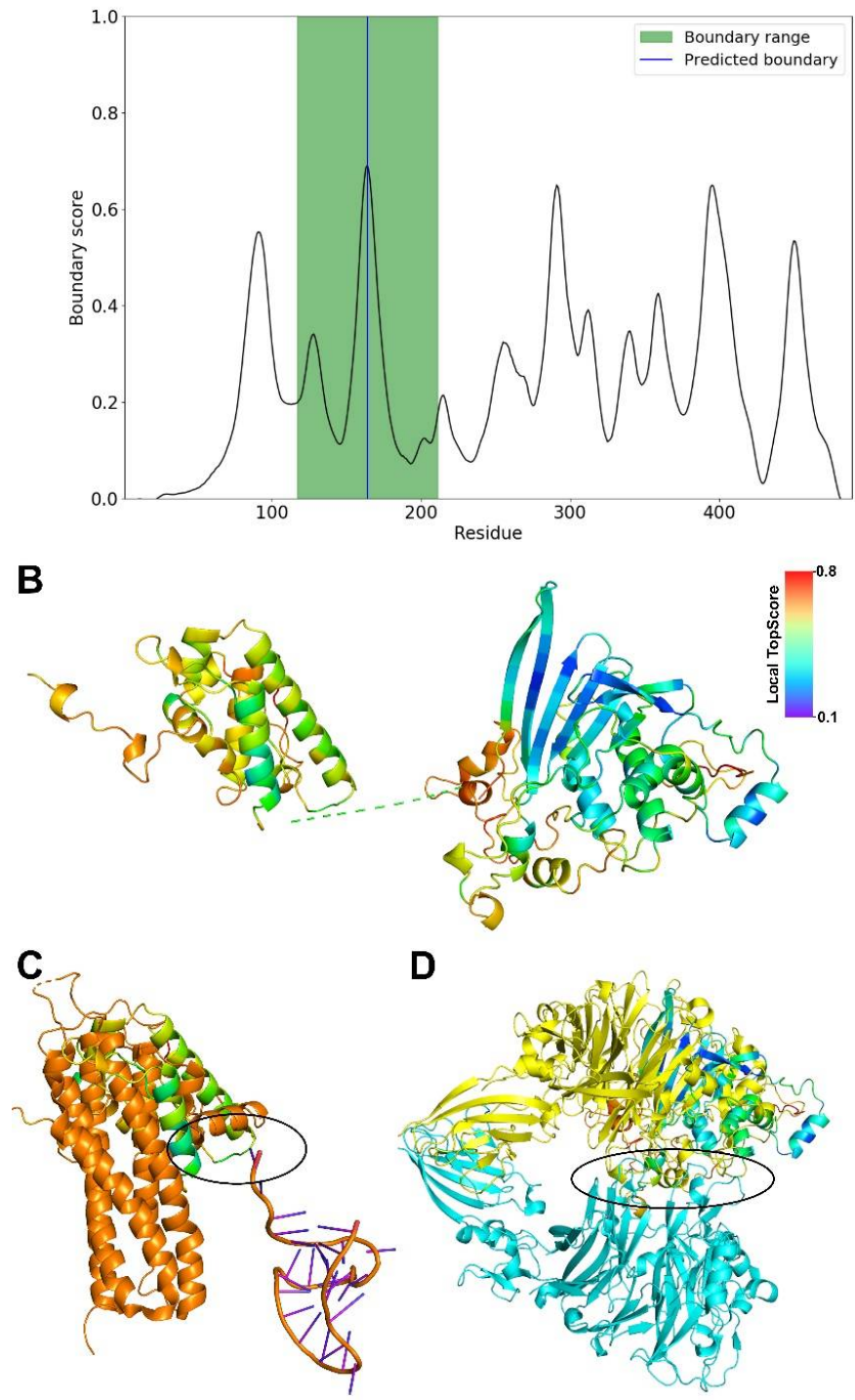

Figure 3. Molecular model of SFV-chimpanzee Bet protein domains. (A) Domain boundaries predicted by TopDomain [222]. The blue line indicates the split of the sequence into two domains (between residues 164 and 165), which were subsequently modeled separately. (B) Domains are shown in cartoon representation. The coloring indicates the quality assessment of the models on a per-residue level by TopScore [223]. Blue: TopScore $=0.1$ (high structural quality), red: TopScore $=0.8$ (low structural quality). The dotted line represents the connection between domain 1 (left, residues 1-164) and domain 2 (right, residues 165-490). Structural models were generated with ROBETTA [217]. The mutual spatial arrangement of both domains is unknown. (C) Overlay of the C-terminal domain and PDB ID 5M0I_C. The interaction region with mRNA is marked in black. The C-terminal domain is colored as in panel B, 5M0I is colored in orange. (D) Overlay of the N-terminal domain and PDB ID 6PQ8_A. The interaction region with chain B of 6PQ8 is marked in black. The C-terminal domain is colored as in panel B, 6PQ8 chain A is colored in yellow, 6PQ8 chain B is colored in blue. 
For the N-terminal domain, the DALI web server [224] identifies the ATP-binding subunit of the KdpFABC complex (6HRA_B) as the closest structural homolog (Z-score $=3.4$, identity $=3 \%$, RMSD $=4.5 \AA$ ), but the overlaying part consists of transmembrane helices. The second best hit (6IKN_A) is also a membrane protein, which we deem inapt for a viral Bet protein. The third best hit (6W2W_A) is a synthetical protein. The fourth best hit (5M0I_C, Z-score $=2.9$, identity $=13 \%$, RMSD $=4.3 \AA$ ) is part of the ASH1 mRNA transportation complex [225] (Figure 3C), from which a potential nucleic acid interaction region can be derived. For the C-terminal domain, the first five hits (4QL0_A, 7BTX_L, 4C00_A, 3CSL_A, 3KVN_X; Z-scores 4.8 to 4.4) from the DALI webserver are structures with $\beta$-sheet barrels, although the predicted domain structure does not form a barrel. The sixth hit is 6QP8_A (Z-score $=4.4$, identity $=3 \%$, RMSD $=4.5 \AA$ ) (Figure 3D), which is part of a signaling cascade and engages in protein-protein interactions [226], from which a potential interaction interface can be derived. The results suggest that the $\mathrm{N}$-terminal domain may be involved in DNA or RNA binding and the C-terminal one in the recruitment of another protein.

Due to the lack of coevolutionary information for residue pairs between the domains, as tested using HDock [227], and the uncertainty of protein-protein docking of unbound structures [228], we refrained from modeling the protein's quaternary structure based on the two domains.

As for the other FV Bet proteins, we expect that the PFV Bet and SFV-macaque Bet proteins have structures similar to the SFV-chimpanzee Bet protein due to sequence identities of $86.2 \%$ and $33.14 \%$, respectively (Figure 2). The FFV Bet protein is sequentially more distant, as indicated that it is not part of the same Pfam [229] entry (PF03274) as the other three Bet proteins.

\section{FV Bet-APOBEC3 Interaction: A Distinct Retroviral Strategy to Protect Viral Genomes without Inducing Degradation of APOBEC3s}

Using FFV Bet and cat CRFK cells, our study in 2005 pioneered the role of Bet in counteracting feline A3 (feA3)-mediated retroviral inhibition [134]. FFV permissive CRFK cells displayed a nonpermissive phenotype when infected with Bet-defective FFV [202], and further investigations uncovered A3-mediated genome editing of FFV $\Delta$ Bet [134]. Of note, in contrast to lentiviruses, the most distinguishing feature is that the deamination activity on viral substrate DNA already occurs in FFV-producing cells, so that edited-proviral DNA genomes are present in released virions. Interestingly, the absence of Bet from FFV genomes resulted in strongly decreased FFV titers, diminished particle release, and attenuated Gag processing, in addition to pronounced genome editing by A3 [134]. Furthermore, FFV Bet binding to feA3, but not human A3G, was observed, indicating a species-specific interaction of these proteins. Whereas feA3 was encapsidated into the virions, Bet was not. This study and follow-up studies further confirmed the specific interaction of FFV Bet with feA3s, which results in A3 sequestration in cells, probably as an "immobile complex", without triggering proteolytic degradation of feline A3s [89,134,158,203,230]. Like FIV Vif, which binds to the different feA3s and promotes their degradation, FFV Bet interacts with all feA3s, independent of whether they restrict the FFV or not [230]. In contrast to Bet-feA3 binding, only some feA3s that contain a Z2 domain (feA3Z2 and feA3Z2-Z3) bind to FFV Gag. This Gag-A3 interaction is found to be crucial for feA3 incorporation into progeny virions and subsequently for restriction $[230,231]$.

Computational analysis of Bet sequences from BFV, EFV, SFV, FFV, PFV, and SloEFV identified six conserved motifs in the Bel2 domain of Bet [89]. The entire FFV Bel2 domain, but not the N-terminal Tas region, is essential for feA3 binding and inactivation [89]. Although the Bel1/Tas motif seems dispensable, intriguingly, it increases the stability of Bet. Hence, both Tas and Bel2 regions are needed for efficient counteraction of feA3 [89]. In addition, this study indicated that the Bel1 region and C-terminal 22 residues of the FFV bel2/bet ORF can be exchanged by related FVs, such as PFV, even though PFV Bet does not bind and counteract feA3Z2. A mechanism for FFV Bet activity has not been identified, but an interaction of FFV Bet and feline A3s was demonstrated to be 
necessary [89,230]. A recent investigation using a cat model and a chimeric FFV system suggests that FIV Vif can replace Bet to counteract feA3 in cell lines and animals. This replacement yielded replication-competent chimeric FFVs that replicated and spread in cell culture but were attenuated in vivo [203]. These findings underscore the essential requirement of Bet and possibly additional functions other than A3 antagonism in vivo for productive FFV infection.

Notably, two earlier studies using the PFV-based viral vector system reported controversial data regarding the function of Bet as an A3G antagonist [130,136]. Russell et al. [136] demonstrated that human A3G and A3F proteins inhibit the infectivity of PFV due to a specific Gag-A3 interaction and induce cytidine deamination in the PFV genomes. They also demonstrated binding of PFV Bet to human A3F and A3G (and rescue of PFV), but not to mA3. Additionally, PFV Bet and Bet from AGM FV could rescue the infectivity of PFV $\triangle$ Bet and Vif-deficient HIV-1 in the presence of AGM A3G by blocking the packaging of A3G into HIV-1 virion particles [136]. Like FFV Bet, these Bet proteins as well did not deplete A3 levels in viral producer cells (Figure 4). In contrast to this report, Delebecque et al. [130] found that A3G and A3F can effectively restrict PFV by their deaminase function, independently of Bet. They also found that in addition to human A3G and A3F, A3G from chimpanzee, AGM, and $\mathrm{mA} 3$ all restricted FV replication in cell culture irrespective of Bet, whereas human $\mathrm{A} 3 \mathrm{~B}$ and $\mathrm{A} 3 \mathrm{C}$ did not inhibit PFV $\triangle \mathrm{Bet}$. Importantly, these authors could not observe a Vif-like activity of Bet, i.e., FV Bet did not rescue HIV-1 $\Delta$ Vif in the presence of human A3G, but this study did not investigate Bet-A3 interaction [130].

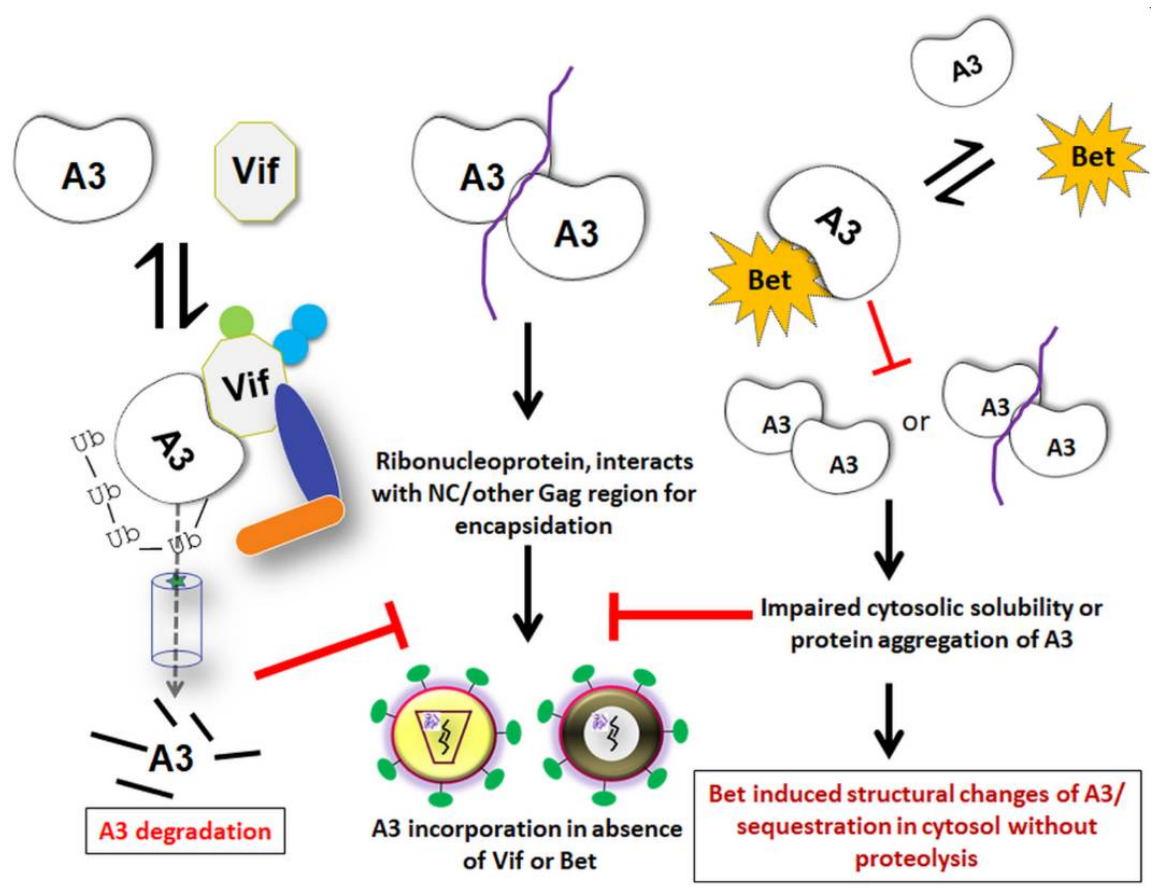

Figure 4. Different modes of suppression of A3 viral incorporation by lentiviral Vif and FV Bet. Schematic representation of APOBEC3 (A3) counteraction strategies developed by lentiviral Vif and foamy viral Bet proteins. While Vif binds and triggers proteasomal degradation of A3 proteins by recruiting an E3 ubiquitin ligase complex (left model), Bet differs from Vif in that it specifically interrupts the self-association of A3s, thereby diminishing their cytosolic solubility without inducing their degradation (right model). Either way, these retroviral accessory proteins overcome A3-mediated inhibition of viral infectivity by depleting/sequestering them away from progeny virions. For simplicity, A3-Vif and A3-Bet complex formation are depicted as two monomers interacting with each other; homodimers of Vif, A3, and Bet are not shown. Only RNA (purple line)-dependent A3 oligomers or A3-A3 dimers are illustrated to indicate for viral incorporation and as a target of Bet inhibition. 
To learn more about mechanistic aspects and functional consequences of Bet binding to A3s, our lab has conducted two independent studies involving A3C and A3G. Both have reported a direct physical interaction of Bet with $A 3 C$ and $A 3 G$, independent of RNA, which traps the A3s in the cytoplasm rendering them unavailable for incorporation into progeny virions $[183,184]$. The Bet-dependent counteraction of A3-mediated restriction was reproduced using SIV-based reporter vectors, in addition to PFV vectors. Although PFV Bet displayed inhibitory activity against a range of simian A3s, it failed to interact with rhesus A3C [184]. Interestingly, the mapped binding site of Bet in A3C and A3G was found to be a region that is involved in A3 homodimerization or multimerization. The PFV Bet interactions with A3s thus impair protein self-association of A3s, without inducing their proteasomal degradation $[183,184]$. RNA-dependent oligomerization of A3s is crucial for their packaging into nascent HIV-1 virions [232], but it has not been investigated in the FV system. While Bet targets the nuclear fraction of $\mathrm{A} 3 \mathrm{C}$ to the cytoplasm, it is unknown whether Bet drags A3C into an insoluble complex or aggregates to keep them immobile [183]. However, it was demonstrated that Bet sequesters A3G in immobile complexes and abrogates the cytosolic solubility of A3G by inhibiting A3G-A3G interaction [183]. Notably, Bet did not inhibit the catalytic activity of A3G, but a direct interaction of purified A3G and Bet proteins was demonstrated [183]. These studies indicate a similar mechanism of inhibition of A3s by Bet, acting mainly when the Bet expression is sufficiently high.

Additionally, our recent study suggested that Bet can counteract A3B without decreasing the steady-state level of A3B [185]. Intriguingly, Bet-A3B complex formation led to the shifting of nuclear A3B to the cytoplasm, therefore affecting its cellular localization. Another salient feature of Bet binding to A3B and A3G was studied by velocity sedimentation as these A3 ribonucleoproteins are found as RNA-bridged high-molecular-mass (HMM) complexes in the cell $[183,185,232-234]$. Bet prevented the HMM complex formation of A3G and A3B. Notably, Bet interaction with A3G was clearly demonstrated to be RNAindependent $[183,185]$. Thus, it would be interesting to understand the impact of Bet on other A3 HMM complexes such as those including A3F and A3C that are either insensitive to RNase or critically stabilized by RNA molecules [235-237]. Because nuclear localization of A3B is a primary cause of and essential for cancer mutations [238-243], this study provides a perspective of using Bet-like proteins to protect host genomes from A3-mutations that cause tumor progression and therapy resistance by targeting nuclear A3B.

\section{Perspectives, Open Questions, and Challenges}

Several investigations identified Bet as a countermeasure to protect viruses from A3s by blocking packaging into progeny virions, a function reminiscent of lentiviral Vif proteins. The reverse transcription complex of FV is not well described, and it is unknown how the antiviral A3 proteins get co-packaged in such complexes. Additional work focusing on A3 interactions with different FV Gag, viral genomic RNA, and DNA is needed to confirm the role of A3 in producer and target cells using both authentic foamy-viral as well as lentiviral systems.

There has been impressive progress in biochemical and structural understanding of A3 and HIV-1 Vif, and molecular studies of purified Bet proteins remain for future work. Likewise, A3 binding motifs of Bet were not comprehensively studied; while the physical interaction of Bet-A3 and Bet binding regions on A3s were demonstrated, we do not know much about the key regions of Bet involved in these interactions. Indeed, structural investigations on Bet will be important, but are complicated by its folding/stability issues (personal communication, see above, Bet structure and function prediction section). Whereas it was demonstrated that Bet impairs the cytosolic solubility of A3s and drags A3s into insoluble complexes in the cell, a direct/indirect function of Bet in shielding viral DNA during RT (late) from A3s in target cells has not been proposed. Additionally, nuclear-localized A3A, A3B, and A3C may impede Gag tethering, genome integration, and transcription of Tas/Bet or LTR-driven viral genes. These open questions and the discovery of currently unknown functions of Bet identification await future research. 
Author Contributions: A.A.J.V. prepared the first draft with C.M.; A.A.J.V. constructed figures. D.B. and H.G. modeled Bet protein and displayed these results. T.L. and C.M. analyzed the figures. All authors have read and agreed to the published version of the manuscript.

Funding: This research received no external funding.

Data Availability Statement: The molecular models can be downloaded from researchdata.hhu.de, the DOI is "http:/ / dx.doi.org/10.25838/d5p-17".

Acknowledgments: C.M. is supported by the Heinz Ansmann Foundation for AIDS research. We thank Dirk Lindemann, Martin Löchelt, and Wolfgang A. Schulz for critically proofreading the manuscript and providing valuable suggestions. H.G. is grateful for computational support and infrastructure provided by the "Zentrum für Informations- und Medientechnologie" (ZIM) at the Heinrich-Heine-University Düsseldorf and the computing time provided by the John von Neumann Institute for Computing (NIC) to HG on the supercomputer JUWELS at Jülich Supercomputing Centre (JSC) (user ID: HKF7)

Conflicts of Interest: The authors declare that no competing interests exist.

\section{References}

1. Enders, J.F.; Peebles, T.C. Propagation in tissue cultures of cytopathogenic agents from patients with measles. Proc. Soc. Exp. Biol. Med. 1954, 86, 277-286. [CrossRef]

2. Rustigian, R.; Johnston, P.; Reihart, H. Infection of monkey kidney tissue cultures with virus-like agents. Proc. Soc. Exp. Biol. Med. 1955, 88, 8-16. [CrossRef]

3. Achong, B.G.; Mansell, P.W.; Epstein, M.A.; Clifford, P. An unusual virus in cultures from a human nasopharyngeal carcinoma. J. Natl. Cancer Inst. 1971, 46, 299-307.

4. Herchenroder, O.; Renne, R.; Loncar, D.; Cobb, E.K.; Murthy, K.K.; Schneider, J.; Mergia, A.; Luciw, P.A. Isolation, cloning, and sequencing of simian foamy viruses from chimpanzees (SFVcpz): High homology to human foamy virus (HFV). Virology 1994, 201, 187-199. [CrossRef] [PubMed]

5. Gessain, A.; Rua, R.; Betsem, E.; Turpin, J.; Mahieux, R. HTLV-3/4 and simian foamy retroviruses in humans: Discovery, epidemiology, cross-species transmission and molecular virology. Virology 2013, 435, 187-199. [CrossRef] [PubMed]

6. Meiering, C.D.; Linial, M.L. Historical perspective of foamy virus epidemiology and infection. Clin. Microbiol. Rev. 2001, 14, 165-176. [CrossRef] [PubMed]

7. Pinto-Santini, D.M.; Stenbak, C.R.; Linial, M.L. Foamy virus zoonotic infections. Retrovirology 2017, 14, 55. [CrossRef]

8. Betsem, E.; Rua, R.; Tortevoye, P.; Froment, A.; Gessain, A. Frequent and recent human acquisition of simian foamy viruses through apes' bites in central Africa. PLoS Pathog. 2011, 7, e1002306. [CrossRef]

9. Boneva, R.S.; Switzer, W.M.; Spira, T.J.; Bhullar, V.B.; Shanmugam, V.; Cong, M.E.; Lam, L.; Heneine, W.; Folks, T.M.; Chapman, L.E. Clinical and virological characterization of persistent human infection with simian foamy viruses. AIDS Res. Hum. Retrovir. 2007, 23, 1330-1337. [CrossRef]

10. Callahan, M.E.; Switzer, W.M.; Matthews, A.L.; Roberts, B.D.; Heneine, W.; Folks, T.M.; Sandstrom, P.A. Persistent zoonotic infection of a human with simian foamy virus in the absence of an intact orf-2 accessory gene. J. Virol. 1999, 73, 9619-9624. [CrossRef]

11. Leendertz, S.A.; Junglen, S.; Hedemann, C.; Goffe, A.; Calvignac, S.; Boesch, C.; Leendertz, F.H. High prevalence, coinfection rate, and genetic diversity of retroviruses in wild red colobus monkeys (Piliocolobus badius badius) in Tai National Park, Cote d'Ivoire. J. Virol. 2010, 84, 7427-7436. [CrossRef]

12. Switzer, W.M.; Tang, S.; Ahuka-Mundeke, S.; Shankar, A.; Hanson, D.L.; Zheng, H.; Ayouba, A.; Wolfe, N.D.; LeBreton, M.; Djoko, C.F.; et al. Novel simian foamy virus infections from multiple monkey species in women from the Democratic Republic of Congo. Retrovirology 2012, 9, 100. [CrossRef]

13. Goldberg, T.L.; Sintasath, D.M.; Chapman, C.A.; Cameron, K.M.; Karesh, W.B.; Tang, S.; Wolfe, N.D.; Rwego, I.B.; Ting, N.; Switzer, W.M. Coinfection of Ugandan red colobus (Procolobus [Piliocolobus] rufomitratus tephrosceles) with novel, divergent delta-, lenti-, and spumaretroviruses. J. Virol. 2009, 83, 11318-11329. [CrossRef]

14. Liu, W.; Worobey, M.; Li, Y.; Keele, B.F.; Bibollet-Ruche, F.; Guo, Y.; Goepfert, P.A.; Santiago, M.L.; Ndjango, J.B.; Neel, C.; et al. Molecular ecology and natural history of simian foamy virus infection in wild-living chimpanzees. PLoS Pathog. 2008, 4, e1000097. [CrossRef]

15. Murray, S.M.; Linial, M.L. Simian Foamy Virus Co-Infections. Viruses 2019, 11, 902. [CrossRef] [PubMed]

16. VandeWoude, S.; Apetrei, C. Going wild: Lessons from naturally occurring T-lymphotropic lentiviruses. Clin. Microbiol. Rev. 2006, 19, 728-762. [CrossRef] [PubMed]

17. Locatelli, S.; Peeters, M. Cross-species transmission of simian retroviruses: How and why they could lead to the emergence of new diseases in the human population. AIDS 2012, 26, 659-673. [CrossRef] [PubMed]

18. Peeters, M.; D'Arc, M.; Delaporte, E. Origin and diversity of human retroviruses. AIDS Rev. 2014, 16, $23-34$.

19. Schweizer, M.; Schleer, H.; Pietrek, M.; Liegibel, J.; Falcone, V.; Neumann-Haefelin, D. Genetic stability of foamy viruses: Long-term study in an African green monkey population. J. Virol. 1999, 73, 9256-9265. [CrossRef] 
20. Holmes, E.C. Evolutionary history and phylogeography of human viruses. Ann. Rev. Microbiol. 2008, 62, 307-328. [CrossRef]

21. Switzer, W.M.; Salemi, M.; Shanmugam, V.; Gao, F.; Cong, M.E.; Kuiken, C.; Bhullar, V.; Beer, B.E.; Vallet, D.; Gautier-Hion, A.; et al. Ancient co-speciation of simian foamy viruses and primates. Nature 2005, 434, 376-380. [CrossRef]

22. Linial, M. Why aren't foamy viruses pathogenic? Trends Microbiol. 2000, 8, 284-289. [CrossRef]

23. Murray, S.M.; Linial, M.L. Foamy virus infection in primates. J. Med. Primatol. 2006, 35, 225-235. [CrossRef] [PubMed]

24. Gärtner, K.; Wiktorowicz, T.; Park, J.; Mergia, A.; Rethwilm, A.; Scheller, C. Accuracy estimation of foamy virus genome copying. Retrovirology 2009, 6, 32. [CrossRef]

25. Jones-Engel, L.; Engel, G.A.; Schillaci, M.A.; Rompis, A.; Putra, A.; Suaryana, K.G.; Fuentes, A.; Beer, B.; Hicks, S.; White, R.; et al. Primate-to-human retroviral transmission in Asia. Emerg. Infect. Dis. 2005, 11, 1028-1035. [CrossRef] [PubMed]

26. Santos, A.F.; Cavalcante, L.T.F.; Muniz, C.P.; Switzer, W.M.; Soares, M.A. Simian Foamy Viruses in Central and South America: A New World of Discovery. Viruses 2019, 11, 967. [CrossRef]

27. Soliven, K.; Wang, X.; Small, C.T.; Feeroz, M.M.; Lee, E.G.; Craig, K.L.; Hasan, K.; Engel, G.A.; Jones-Engel, L.; Matsen, F.A.t.; et al. Simian foamy virus infection of rhesus macaques in Bangladesh: Relationship of latent proviruses and transcriptionally active viruses. J. Virol. 2013, 87, 13628-13639. [CrossRef]

28. Jones-Engel, L.; May, C.C.; Engel, G.A.; Steinkraus, K.A.; Schillaci, M.A.; Fuentes, A.; Rompis, A.; Chalise, M.K.; Aggimarangsee, N.; Feeroz, M.M.; et al. Diverse contexts of zoonotic transmission of simian foamy viruses in Asia. Emerg. Infect. Dis. 2008, 14, 1200-1208. [CrossRef]

29. Schweizer, M.; Turek, R.; Hahn, H.; Schliephake, A.; Netzer, K.O.; Eder, G.; Reinhardt, M.; Rethwilm, A.; Neumann-Haefelin, D. Markers of foamy virus infections in monkeys, apes, and accidentally infected humans: Appropriate testing fails to confirm suspected foamy virus prevalence in humans. AIDS Res. Hum. Retrovir. 1995, 11, 161-170. [CrossRef]

30. Switzer, W.M.; Bhullar, V.; Shanmugam, V.; Cong, M.E.; Parekh, B.; Lerche, N.W.; Yee, J.L.; Ely, J.J.; Boneva, R.; Chapman, L.E.; et al. Frequent simian foamy virus infection in persons occupationally exposed to nonhuman primates. J. Virol. 2004, 78, 2780-2789. [CrossRef] [PubMed]

31. Wolfe, N.D.; Switzer, W.M.; Carr, J.K.; Bhullar, V.B.; Shanmugam, V.; Tamoufe, U.; Prosser, A.T.; Torimiro, J.N.; Wright, A.; MpoudiNgole, E.; et al. Naturally acquired simian retrovirus infections in central African hunters. Lancet 2004, 363, 932-937. [CrossRef]

32. Huang, F.; Wang, H.; Jing, S.; Zeng, W. Simian foamy virus prevalence in Macaca mulatta and zookeepers. AIDS Res. Hum. Retrovir. 2012, 28, 591-593. [CrossRef] [PubMed]

33. Mouinga-Ondeme, A.; Betsem, E.; Caron, M.; Makuwa, M.; Salle, B.; Renault, N.; Saib, A.; Telfer, P.; Marx, P.; Gessain, A.; et al. Two distinct variants of simian foamy virus in naturally infected mandrills (Mandrillus sphinx) and cross-species transmission to humans. Retrovirology 2010, 7, 105. [CrossRef] [PubMed]

34. Mouinga-Ondeme, A.; Caron, M.; Nkoghe, D.; Telfer, P.; Marx, P.; Saib, A.; Leroy, E.; Gonzalez, J.P.; Gessain, A.; Kazanji, M. Cross-species transmission of simian foamy virus to humans in rural Gabon, Central Africa. J. Virol. 2012, 86, 1255-1260. [CrossRef] [PubMed]

35. Khan, A.S. Simian foamy virus infection in humans: Prevalence and management. Expert Rev. Anti-Infect. Ther. 2009, 7, 569-580. [CrossRef] [PubMed]

36. Mouinga-Ondeme, A.; Kazanji, M. Simian foamy virus in non-human primates and cross-species transmission to humans in Gabon: An emerging zoonotic disease in central Africa? Viruses 2013, 5, 1536-1552. [CrossRef]

37. Riggs, J.L.; Oshiro, L.S.; Taylor, D.O.; Lennette, E.H. Syncytium-forming agent isolated from domestic cats. Nature 1969, 222, 1190-1191. [CrossRef]

38. Winkler, I.G.; Flugel, R.M.; Löchelt, M.; Flower, R.L. Detection and molecular characterisation of feline foamy virus serotypes in naturally infected cats. Virology 1998, 247, 144-151. [CrossRef]

39. Kehl, T.; Bleiholder, A.; Rossmann, F.; Rupp, S.; Lei, J.; Lee, J.; Boyce, W.; Vickers, W.; Crooks, K.; Vandewoude, S.; et al. Complete Genome Sequences of Two Novel Puma concolor Foamy Viruses from California. Genome Announc. 2013, 1, e0020112. [CrossRef]

40. Hechler, T.; Materniak, M.; Kehl, T.; Kuzmak, J.; Löchelt, M. Complete genome sequences of two novel European clade bovine foamy viruses from Germany and Poland. J. Virol. 2012, 86, 10905-10906. [CrossRef]

41. Malmquist, W.A.; Van der Maaten, M.J.; Boothe, A.D. Isolation, immunodiffusion, immunofluorescence, and electron microscopy of a syncytial virus of lymphosarcomatous and apparently normal cattle. Cancer Res. 1969, 29, 188-200.

42. Materniak, M.; Bicka, L.; Kuzmak, J. Isolation and partial characterization of bovine foamy virus from Polish cattle. Pol. J. Vet. Sci. 2006, 9, 207-211.

43. Tobaly-Tapiero, J.; Bittoun, P.; Neves, M.; Guillemin, M.C.; Lecellier, C.H.; Puvion-Dutilleul, F.; Gicquel, B.; Zientara, S.; Giron, M.L.; de The, H.; et al. Isolation and characterization of an equine foamy virus. J. Virol. 2000, 74, 4064-4073. [CrossRef] [PubMed]

44. Wu, Z.; Ren, X.; Yang, L.; Hu, Y.; Yang, J.; He, G.; Zhang, J.; Dong, J.; Sun, L.; Du, J.; et al. Virome analysis for identification of novel mammalian viruses in bat species from Chinese provinces. J. Virol. 2012, 86, 10999-11012. [CrossRef] [PubMed]

45. Kehl, T.; Tan, J.; Materniak, M. Non-simian foamy viruses: Molecular virology, tropism and prevalence and zoonotic/interspecies transmission. Viruses 2013, 5, 2169-2209. [CrossRef]

46. Materniak-Kornas, M.; Tan, J.; Heit-Mondrzyk, A.; Hotz-Wagenblatt, A.; Löchelt, M. Bovine Foamy Virus: Shared and Unique Molecular Features in vitro and in vivo. Viruses 2019, 11, 1084. [CrossRef]

47. Saib, A. Non-primate foamy viruses. Curr. Top. Microbiol. Immunol. 2003, 277, 197-211. 
48. Renshaw, R.W.; Casey, J.W. Transcriptional mapping of the 3' end of the bovine syncytial virus genome. J. Virol. 1994, 68, 1021-1028. [CrossRef]

49. Romen, F.; Backes, P.; Materniak, M.; Sting, R.; Vahlenkamp, T.W.; Riebe, R.; Pawlita, M.; Kuzmak, J.; Löchelt, M. Serological detection systems for identification of cows shedding bovine foamy virus via milk. Virology 2007, 364, 123-131. [CrossRef]

50. Winkler, I.G.; Löchelt, M.; Flower, R.L. Epidemiology of feline foamy virus and feline immunodeficiency virus infections in domestic and feral cats: A seroepidemiological study. J. Clin. Microbiol. 1999, 37, 2848-2851. [CrossRef] [PubMed]

51. Kirisawa, R.; Toishi, Y.; Hashimoto, H.; Tsunoda, N. Isolation of an Equine Foamy Virus and Sero-Epidemiology of the Viral Infection in Horses in Japan. Viruses 2019, 11, 613. [CrossRef] [PubMed]

52. Holmes, E.C. The evolution of endogenous viral elements. Cell Host Microbe 2011, 10, 368-377. [CrossRef] [PubMed]

53. Katzourakis, A.; Gifford, R.J. Endogenous viral elements in animal genomes. PLoS Genet. 2010, 6, e1001191. [CrossRef] [PubMed]

54. Han, G.Z.; Worobey, M. An endogenous foamy virus in the aye-aye (Daubentonia madagascariensis). J. Virol. 2012, 86, 7696-7698. [CrossRef] [PubMed]

55. Katzourakis, A.; Gifford, R.J.; Tristem, M.; Gilbert, M.T.; Pybus, O.G. Macroevolution of complex retroviruses. Science 2009, 325, 1512. [CrossRef] [PubMed]

56. Schartl, M.; Walter, R.B.; Shen, Y.; Garcia, T.; Catchen, J.; Amores, A.; Braasch, I.; Chalopin, D.; Volff, J.N.; Lesch, K.P.; et al. The genome of the platyfish, Xiphophorus maculatus, provides insights into evolutionary adaptation and several complex traits. Nat. Genet. 2013, 45, 567-572. [CrossRef]

57. Armitage, A.E.; Deforche, K.; Chang, C.H.; Wee, E.; Kramer, B.; Welch, J.J.; Gerstoft, J.; Fugger, L.; McMichael, A.; Rambaut, A.; et al. APOBEC3G-Induced Hypermutation of Human Immunodeficiency Virus Type-1 Is Typically a Discrete "All or Nothing" Phenomenon. PLoS Genet. 2012, 8, e1002550. [CrossRef]

58. Aiewsakun, P.; Katzourakis, A. Marine origin of retroviruses in the early Palaeozoic Era. Nat. Commun. 2017, 8, 13954. [CrossRef] [PubMed]

59. Aiewsakun, P. Avian and serpentine endogenous foamy viruses, and new insights into the macroevolutionary history of foamy viruses. Virus Evol. 2020, 6, vez057. [CrossRef]

60. Aiewsakun, P.; Simmonds, P.; Katzourakis, A. The First Co-Opted Endogenous Foamy Viruses and the Evolutionary History of Reptilian Foamy Viruses. Viruses 2019, 11, 641. [CrossRef]

61. Chen, Y.; Wei, X.; Zhang, G.; Holmes, E.C.; Cui, J. Identification and evolution of avian endogenous foamy viruses. Virus Evol. 2019, 5, vez049. [CrossRef]

62. Wei, X.; Chen, Y.; Duan, G.; Holmes, E.C.; Cui, J. A reptilian endogenous foamy virus sheds light on the early evolution of retroviruses. Virus Evol. 2019, 5, vez001. [CrossRef] [PubMed]

63. Rethwilm, A.; Bodem, J. Evolution of foamy viruses: The most ancient of all retroviruses. Viruses 2013, 5, 2349-2374 [CrossRef] [PubMed]

64. Bodem, J.; Löchelt, M.; Delius, H.; Flügel, R.M. Detection of subgenomic cDNAs and mapping of feline foamy virus mRNAs reveals complex patterns of transcription. Virology 1998, 244, 417-426. [CrossRef] [PubMed]

65. Enssle, J.; Jordan, I.; Mauer, B.; Rethwilm, A. Foamy virus reverse transcriptase is expressed independently from the Gag protein. Proc. Natl. Acad. Sci. USA 1996, 93, 4137-4141. [CrossRef]

66. Löchelt, M.; Flügel, R.M. The human foamy virus pol gene is expressed as a Pro-Pol polyprotein and not as a Gag-Pol fusion protein. J. Virol. 1996, 70, 1033-1040. [CrossRef] [PubMed]

67. Yu, S.F.; Baldwin, D.N.; Gwynn, S.R.; Yendapalli, S.; Linial, M.L. Human foamy virus replication: A pathway distinct from that of retroviruses and hepadnaviruses. Science 1996, 271, 1579-1582. [CrossRef] [PubMed]

68. Müllers, E. The foamy virus Gag proteins: What makes them different? Viruses 2013, 5, 1023-1041. [CrossRef] [PubMed]

69. Giron, M.L.; Colas, S.; Wybier, J.; Rozain, F.; Emanoil-Ravier, R. Expression and maturation of human foamy virus Gag precursor polypeptides. J. Virol. 1997, 71, 1635-1639. [CrossRef]

70. Pfrepper, K.I.; Löchelt, M.; Rackwitz, H.R.; Schnolzer, M.; Heid, H.; Flügel, R.M. Molecular characterization of proteolytic processing of the Gag proteins of human spumavirus. J. Virol. 1999, 73, 7907-7911. [CrossRef]

71. Enssle, J.; Fischer, N.; Moebes, A.; Mauer, B.; Smola, U.; Rethwilm, A. Carboxy-terminal cleavage of the human foamy virus Gag precursor molecule is an essential step in the viral life cycle. J. Virol. 1997, 71, 7312-7317. [CrossRef] [PubMed]

72. Zemba, M.; Wilk, T.; Rutten, T.; Wagner, A.; Flügel, R.M.; Löchelt, M. The carboxy-terminal p3Gag domain of the human foamy virus Gag precursor is required for efficient virus infectivity. Virology 1998, 247, 7-13. [CrossRef] [PubMed]

73. Heinkelein, M.; Leurs, C.; Rammling, M.; Peters, K.; Hanenberg, H.; Rethwilm, A. Pregenomic RNA is required for efficient incorporation of pol polyprotein into foamy virus capsids. J. Virol. 2002, 76, 10069-10073. [CrossRef]

74. Peters, K.; Wiktorowicz, T.; Heinkelein, M.; Rethwilm, A. RNA and protein requirements for incorporation of the Pol protein into foamy virus particles. J. Virol. 2005, 79, 7005-7013. [CrossRef] [PubMed]

75. Rethwilm, A. Specific RNA-protein interactions in the replication of foamy viruses (FVs). Curr. Opin. Virol. 2013, 3, 676-683. [CrossRef]

76. Wöhrl, B.M. Structural and Functional Aspects of Foamy Virus Protease-Reverse Transcriptase. Viruses 2019, 11, 598. [CrossRef]

77. Boyer, P.L.; Stenbak, C.R.; Clark, P.K.; Linial, M.L.; Hughes, S.H. Characterization of the polymerase and RNase H activities of human foamy virus reverse transcriptase. J. Virol. 2004, 78, 6112-6121. [CrossRef] 
78. Cartellieri, M.; Rudolph, W.; Herchenroder, O.; Lindemann, D.; Rethwilm, A. Determination of the relative amounts of Gag and Pol proteins in foamy virus particles. Retrovirology 2005, 2, 44. [CrossRef]

79. Lee, E.G.; Stenbak, C.R.; Linial, M.L. Foamy virus assembly with emphasis on pol encapsidation. Viruses 2013, 5, 886-900. [CrossRef] [PubMed]

80. Rinke, C.S.; Boyer, P.L.; Sullivan, M.D.; Hughes, S.H.; Linial, M.L. Mutation of the catalytic domain of the foamy virus reverse transcriptase leads to loss of processivity and infectivity. J. Virol. 2002, 76, 7560-7570. [CrossRef]

81. Moebes, A.; Enssle, J.; Bieniasz, P.D.; Heinkelein, M.; Lindemann, D.; Bock, M.; McClure, M.O.; Rethwilm, A. Human foamy virus reverse transcription that occurs late in the viral replication cycle. J. Virol. 1997, 71, 7305-7311. [CrossRef] [PubMed]

82. Zamborlini, A.; Renault, N.; Saib, A.; Delelis, O. Early reverse transcription is essential for productive foamy virus infection. PLoS ONE 2010, 5, e11023. [CrossRef] [PubMed]

83. Cain, D.; Erlwein, O.; Grigg, A.; Russell, R.A.; McClure, M.O. Palindromic sequence plays a critical role in human foamy virus dimerization. J. Virol. 2001, 75, 3731-3739. [CrossRef] [PubMed]

84. Erlwein, O.; Cain, D.; Fischer, N.; Rethwilm, A.; McClure, M.O. Identification of sites that act together to direct dimerization of human foamy virus RNA in vitro. Virology 1997, 229, 251-258. [CrossRef] [PubMed]

85. Gramberg, T.; Kahle, T.; Bloch, N.; Wittmann, S.; Mullers, E.; Daddacha, W.; Hofmann, H.; Kim, B.; Lindemann, D.; Landau, N.R. Restriction of diverse retroviruses by SAMHD1. Retrovirology 2013, 10, 26. [CrossRef]

86. Yu, S.F.; Sullivan, M.D.; Linial, M.L. Evidence that the human foamy virus genome is DNA. J. Virol. 1999, 73, 1565-1572. [CrossRef]

87. Delelis, O.; Saib, A.; Sonigo, P. Biphasic DNA synthesis in spumaviruses. J. Virol. 2003, 77, 8141-8146. [CrossRef]

88. Bergez, M.; Weber, J.; Riess, M.; Erdbeer, A.; Seifried, J.; Stanke, N.; Munz, C.; Hornung, V.; Konig, R.; Lindemann, D. Insights into Innate Sensing of Prototype Foamy Viruses in Myeloid Cells. Viruses 2019, 11, 1095. [CrossRef]

89. Lukic, D.S.; Hotz-Wagenblatt, A.; Lei, J.; Rathe, A.M.; Muhle, M.; Denner, J.; Münk, C.; Löchelt, M. Identification of the feline foamy virus Bet domain essential for APOBEC3 counteraction. Retrovirology 2013, 10, 76. [CrossRef]

90. Hamann, M.V.; Lindemann, D. Foamy Virus Protein-Nucleic Acid Interactions during Particle Morphogenesis. Viruses 2016, 8, 243. [CrossRef] [PubMed]

91. Lindemann, D.; Goepfert, P.A. The foamy virus envelope glycoproteins. Curr. Top. Microbiol. Immunol. 2003, 277, 111-129.

92. Jaguva Vasudevan, A.A. APOBEC3 DNA Deaminases: A Mechanistic Study of A3A, A3C, and A3G Action on Retroviruses and Counteraction by Viral Proteins; Heinrich Heine University: Düsseldorf, Germany, 2017.

93. Bieniasz, P.D.; Rethwilm, A.; Pitman, R.; Daniel, M.D.; Chrystie, I.; McClure, M.O. A comparative study of higher primate foamy viruses, including a new virus from a gorilla. Virology 1995, 207, 217-228. [CrossRef] [PubMed]

94. Patton, G.S.; Erlwein, O.; McClure, M.O. Cell-cycle dependence of foamy virus vectors. J. Gen. Virol. 2004, 85, 2925-2930. [CrossRef] [PubMed]

95. Suzuki, Y.; Craigie, R. The road to chromatin-Nuclear entry of retroviruses. Nat. Rev. Microbiol. 2007, 5, 187-196. [CrossRef]

96. Trobridge, G.; Russell, D.W. Cell cycle requirements for transduction by foamy virus vectors compared to those of oncovirus and lentivirus vectors. J. Virol. 2004, 78, 2327-2335. [CrossRef]

97. Hill, C.L.; Bieniasz, P.D.; McClure, M.O. Properties of human foamy virus relevant to its development as a vector for gene therapy. J. Gen. Virol. 1999, 80, 2003-2009. [CrossRef] [PubMed]

98. Mergia, A.; Leung, N.J.; Blackwell, J. Cell tropism of the simian foamy virus type 1 (SFV-1). J. Med. Primatol. 1996, 25, 2-7. [CrossRef]

99. Nasimuzzaman, M.; Persons, D.A. Cell Membrane-associated heparan sulfate is a receptor for prototype foamy virus in human, monkey, and rodent cells. Mol. Ther. 2012, 20, 1158-1166. [CrossRef] [PubMed]

100. Plochmann, K.; Horn, A.; Gschmack, E.; Armbruster, N.; Krieg, J.; Wiktorowicz, T.; Weber, C.; Stirnnagel, K.; Lindemann, D.; Rethwilm, A.; et al. Heparan sulfate is an attachment factor for foamy virus entry. J. Virol. 2012, 86, 10028-10035. [CrossRef]

101. Lesbats, P.; Serrao, E.; Maskell, D.P.; Pye, V.E.; O’Reilly, N.; Lindemann, D.; Engelman, A.N.; Cherepanov, P. Structural basis for spumavirus GAG tethering to chromatin. Proc. Natl. Acad. Sci. USA 2017, 114, 5509-5514. [CrossRef]

102. Saib, A.; Puvion-Dutilleul, F.; Schmid, M.; Peries, J.; de The, H. Nuclear targeting of incoming human foamy virus Gag proteins involves a centriolar step. J. Virol. 1997, 71, 1155-1161. [CrossRef]

103. Stirnnagel, K.; Schupp, D.; Dupont, A.; Kudryavtsev, V.; Reh, J.; Mullers, E.; Lamb, D.C.; Lindemann, D. Differential pHdependent cellular uptake pathways among foamy viruses elucidated using dual-colored fluorescent particles. Retrovirology 2012, 9, 71. [CrossRef]

104. Tobaly-Tapiero, J.; Bittoun, P.; Lehmann-Che, J.; Delelis, O.; Giron, M.L.; de The, H.; Saib, A. Chromatin tethering of incoming foamy virus by the structural Gag protein. Traffic 2008, 9, 1717-1727. [CrossRef]

105. Berka, U.; Hamann, M.V.; Lindemann, D. Early events in foamy virus-host interaction and intracellular trafficking. Viruses 2013, 5, 1055-1074. [CrossRef] [PubMed]

106. Lee, G.E.; Mauro, E.; Parissi, V.; Shin, C.G.; Lesbats, P. Structural Insights on Retroviral DNA Integration: Learning from Foamy Viruses. Viruses 2019, 11, 770. [CrossRef] [PubMed]

107. Falcone, V.; Leupold, J.; Clotten, J.; Urbanyi, E.; Herchenroder, O.; Spatz, W.; Volk, B.; Bohm, N.; Toniolo, A.; Neumann-Haefelin, D.; et al. Sites of simian foamy virus persistence in naturally infected African green monkeys: Latent provirus is ubiquitous, whereas viral replication is restricted to the oral mucosa. Virology 1999, 257, 7-14. [CrossRef] 
108. Materniak, M.; Hechler, T.; Löchelt, M.; Kuzmak, J. Similar patterns of infection with bovine foamy virus in experimentally inoculated calves and sheep. J. Virol. 2013, 87, 3516-3525. [CrossRef] [PubMed]

109. Rua, R.; Betsem, E.; Montange, T.; Buseyne, F.; Gessain, A. In vivo cellular tropism of gorilla simian foamy virus in blood of infected humans. J. Virol. 2014, 88, 13429-13435. [CrossRef] [PubMed]

110. von Laer, D.; Neumann-Haefelin, D.; Heeney, J.L.; Schweizer, M. Lymphocytes are the major reservoir for foamy viruses in peripheral blood. Virology 1996, 221, 240-244. [CrossRef]

111. Murray, S.M.; Picker, L.J.; Axthelm, M.K.; Hudkins, K.; Alpers, C.E.; Linial, M.L. Replication in a superficial epithelial cell niche explains the lack of pathogenicity of primate foamy virus infections. J. Virol. 2008, 82, 5981-5985. [CrossRef] [PubMed]

112. Buseyne, F.; Betsem, E.; Montange, T.; Njouom, R.; Bilounga Ndongo, C.; Hermine, O.; Gessain, A. Clinical Signs and Blood Test Results Among Humans Infected with Zoonotic Simian Foamy Virus: A Case-Control Study. J. Infect. Dis. 2018, 218, 144-151. [CrossRef] [PubMed]

113. Gessain, A.; Montange, T.; Betsem, E.; Bilounga Ndongo, C.; Njouom, R.; Buseyne, F. Case-Control Study of the Immune Status of Humans Infected with Zoonotic Gorilla Simian Foamy Viruses. J. Infect. Dis. 2020, 221, 1724-1733. [CrossRef] [PubMed]

114. Ledesma-Feliciano, C.; Troyer, R.M.; Zheng, X.; Miller, C.; Cianciolo, R.; Bordicchia, M.; Dannemiller, N.; Gagne, R.; Beatty, J.; Quimby, J.; et al. Feline Foamy Virus Infection: Characterization of Experimental Infection and Prevalence of Natural Infection in Domestic Cats with and without Chronic Kidney Disease. Viruses 2019, 11, 662. [CrossRef] [PubMed]

115. Colas, S.; Bourge, J.F.; Wybier, J.; Chelbi-Alix, M.K.; Paul, P.; Emanoil-Ravier, R. Human foamy virus infection activates class I major histocompatibility complex antigen expression. J. Gen. Virol. 1995, 76, 661-667. [CrossRef]

116. Rhodes-Feuillette, A.; Saal, F.; Lasneret, J.; Santillana-Hayat, M.; Peries, J. Studies on in vitro interferon induction capacity and interferon sensitivity of simian foamy viruses. Arch. Virol. 1987, 97, 77-84. [CrossRef]

117. Sabile, A.; Rhodes-Feuillette, A.; Jaoui, F.Z.; Tobaly-Tapiero, J.; Giron, M.L.; Lasneret, J.; Peries, J.; Canivet, M. In vitro studies on interferon-inducing capacity and sensitivity to IFN of human foamy virus. Res. Virol. 1996, 147, 29-37. [CrossRef]

118. Rua, R.; Lepelley, A.; Gessain, A.; Schwartz, O. Innate sensing of foamy viruses by human hematopoietic cells. J. Virol. 2012, 86, 909-918. [CrossRef]

119. Falcone, V.; Schweizer, M.; Toniolo, A.; Neumann-Haefelin, D.; Meyerhans, A. Gamma interferon is a major suppressive factor produced by activated human peripheral blood lymphocytes that is able to inhibit foamy virus-induced cytopathic effects. J. Virol. 1999, 73, 1724-1728. [CrossRef]

120. Matthes, D.; Wiktorowicz, T.; Zahn, J.; Bodem, J.; Stanke, N.; Lindemann, D.; Rethwilm, A. Basic residues in the foamy virus Gag protein. J. Virol. 2011, 85, 3986-3995. [CrossRef]

121. Meiering, C.D.; Linial, M.L. The promyelocytic leukemia protein does not mediate foamy virus latency in vitro. J. Virol. 2003, 77 , 2207-2213. [CrossRef]

122. Regad, T.; Saib, A.; Lallemand-Breitenbach, V.; Pandolfi, P.P.; de The, H.; Chelbi-Alix, M.K. PML mediates the interferon-induced antiviral state against a complex retrovirus via its association with the viral transactivator. EMBO J. 2001, 20, 3495-3505. [CrossRef]

123. Rhodes-Feuillette, A.; Lasneret, J.; Paulien, S.; Ogunkolade, W.; Peries, J.; Canivet, M. Effects of human recombinant alpha and gamma and of highly purified natural beta interferons on simian Spumavirinae prototype (simian foamy virus 1) multiplication in human cells. Res. Virol. 1990, 141, 31-43. [CrossRef]

124. Bähr, A.; Singer, A.; Hain, A.; Vasudevan, A.A.; Schilling, M.; Reh, J.; Riess, M.; Panitz, S.; Serrano, V.; Schweizer, M.; et al. Interferon but not MxB inhibits foamy retroviruses. Virology 2016, 488, 51-60. [CrossRef]

125. Couteaudier, M.; Calzada-Fraile, D.; Montange, T.; Gessain, A.; Buseyne, F. Inhibitors of the interferon response increase the replication of gorilla simian foamy viruses. Virology 2020, 541, 25-31. [CrossRef]

126. Zheng, Y.; Zhu, G.; Yan, J.; Tang, Y.; Han, S.; Yin, J.; Peng, B.; He, X.; Liu, W. The Late Domain of Prototype Foamy Virus Gag Facilitates Autophagic Clearance of Stress Granules by Promoting Amphisome Formation. J. Virol. 2020, 94, e01719-19. [CrossRef] [PubMed]

127. Whisnant, A.W.; Kehl, T.; Bao, Q.; Materniak, M.; Kuzmak, J.; Löchelt, M.; Cullen, B.R. Identification of novel, highly expressed retroviral microRNAs in cells infected by bovine foamy virus. J. Virol. 2014, 88, 4679-4686. [CrossRef]

128. Kincaid, R.P.; Chen, Y.; Cox, J.E.; Rethwilm, A.; Sullivan, C.S. Noncanonical microRNA (miRNA) biogenesis gives rise to retroviral mimics of lymphoproliferative and immunosuppressive host miRNAs. mBio 2014, 5, e00074. [CrossRef]

129. Cao, W.; Stricker, E.; Hotz-Wagenblatt, A.; Heit-Mondrzyk, A.; Pougialis, G.; Hugo, A.; Kuzmak, J.; Materniak-Kornas, M.; Löchelt, M. Functional Analyses of Bovine Foamy Virus-Encoded miRNAs Reveal the Importance of a Defined miRNA for Virus Replication and Host-Virus Interaction. Viruses 2020, 12, 1250. [CrossRef] [PubMed]

130. Delebecque, F.; Suspene, R.; Calattini, S.; Casartelli, N.; Saib, A.; Froment, A.; Wain-Hobson, S.; Gessain, A.; Vartanian, J.P.; Schwartz, O. Restriction of foamy viruses by APOBEC cytidine deaminases. J. Virol. 2006, 80, 605-614. [CrossRef]

131. Dietrich, I.; McMonagle, E.L.; Petit, S.J.; Vijayakrishnan, S.; Logan, N.; Chan, C.N.; Towers, G.J.; Hosie, M.J.; Willett, B.J. Feline tetherin efficiently restricts release of feline immunodeficiency virus but not spreading of infection. J. Virol. 2011, 85, 5840-5852. [CrossRef] [PubMed]

132. Jouvenet, N.; Neil, S.J.; Zhadina, M.; Zang, T.; Kratovac, Z.; Lee, Y.; McNatt, M.; Hatziioannou, T.; Bieniasz, P.D. Broad-spectrum inhibition of retroviral and filoviral particle release by tetherin. J. Virol. 2009, 83, 1837-1844. [CrossRef]

133. Kane, M.; Mele, V.; Liberatore, R.A.; Bieniasz, P.D. Inhibition of spumavirus gene expression by PHF11. PLoS Pathog. 2020, 16, e1008644. [CrossRef] 
134. Löchelt, M.; Romen, F.; Bastone, P.; Muckenfuss, H.; Kirchner, N.; Kim, Y.B.; Truyen, U.; Rösler, U.; Battenberg, M.; Saib, A.; et al. The antiretroviral activity of APOBEC3 is inhibited by the foamy virus accessory Bet protein. Proc. Natl. Acad. Sci. USA 2005, 102, 7982-7987. [CrossRef]

135. Pacheco, B.; Finzi, A.; McGee-Estrada, K.; Sodroski, J. Species-specific inhibition of foamy viruses from South American monkeys by New World Monkey TRIM5\{alpha\} proteins. J. Virol. 2010, 84, 4095-4099. [CrossRef]

136. Russell, R.A.; Wiegand, H.L.; Moore, M.D.; Schafer, A.; McClure, M.O.; Cullen, B.R. Foamy virus Bet proteins function as novel inhibitors of the APOBEC3 family of innate antiretroviral defense factors. J. Virol. 2005, 79, 8724-8731. [CrossRef]

137. Xu, F.; Tan, J.; Liu, R.; Xu, D.; Li, Y.; Geng, Y.; Liang, C.; Qiao, W. Tetherin inhibits prototypic foamy virus release. Virol. J. 2011, 8, 198. [CrossRef] [PubMed]

138. Yap, M.W.; Colbeck, E.; Ellis, S.A.; Stoye, J.P. Evolution of the retroviral restriction gene Fv1: Inhibition of non-MLV retroviruses. PLoS Pathog. 2014, 10, e1003968. [CrossRef]

139. Yap, M.W.; Lindemann, D.; Stanke, N.; Reh, J.; Westphal, D.; Hanenberg, H.; Ohkura, S.; Stoye, J.P. Restriction of foamy viruses by primate Trim5alpha. J. Virol. 2008, 82, 5429-5439. [CrossRef] [PubMed]

140. Boso, G.; Kozak, C.A. Retroviral Restriction Factors and Their Viral Targets: Restriction Strategies and Evolutionary Adaptations. Microorganisms 2020, 8, 1965. [CrossRef] [PubMed]

141. Kim, J.; Shin, C.G. IFITM proteins inhibit the late step of feline foamy virus replication. Anim. Cells Syst. 2020, 24, 282-288. [CrossRef] [PubMed]

142. Tan, J.; Qiao, W.; Wang, J.; Xu, F.; Li, Y.; Zhou, J.; Chen, Q.; Geng, Y. IFP35 is involved in the antiviral function of interferon by association with the viral tas transactivator of bovine foamy virus. J. Virol. 2008, 82, 4275-4283. [CrossRef] [PubMed]

143. Goldstone, D.C.; Flower, T.G.; Ball, N.J.; Sanz-Ramos, M.; Yap, M.W.; Ogrodowicz, R.W.; Stanke, N.; Reh, J.; Lindemann, D.; Stoye, J.P.; et al. A unique spumavirus Gag N-terminal domain with functional properties of orthoretroviral matrix and capsid. PLoS Pathog. 2013, 9, e1003376. [CrossRef] [PubMed]

144. Li, W.; Yap, M.W.; Voss, V.; Stoye, J.P. Expression levels of Fv1: Effects on retroviral restriction specificities. Retrovirology 2016, 13, 42. [CrossRef] [PubMed]

145. Dong, L.; Cheng, Q.; Wang, Z.; Yuan, P.; Li, Z.; Sun, Y.; Han, S.; Yin, J.; Peng, B.; He, X.; et al. Human Pirh2 is a novel inhibitor of prototype foamy virus replication. Viruses 2015, 7, 1668-1684. [CrossRef] [PubMed]

146. Hu, X.; Yang, W.; Liu, R.; Geng, Y.; Qiao, W.; Tan, J. N-Myc interactor inhibits prototype foamy virus by sequestering viral Tas protein in the cytoplasm. J. Virol. 2014, 88, 7036-7044. [CrossRef] [PubMed]

147. Matsen, F.A.t.; Small, C.T.; Soliven, K.; Engel, G.A.; Feeroz, M.M.; Wang, X.; Craig, K.L.; Hasan, M.K.; Emerman, M.; Linial, M.L.; et al. A novel Bayesian method for detection of APOBEC3-mediated hypermutation and its application to zoonotic transmission of simian foamy viruses. PLoS Comput. Biol. 2014, 10, e1003493. [CrossRef] [PubMed]

148. LaRue, R.S.; Jonsson, S.R.; Silverstein, K.A.; Lajoie, M.; Bertrand, D.; El-Mabrouk, N.; Hotzel, I.; Andresdottir, V.; Smith, T.P.; Harris, R.S. The artiodactyl APOBEC3 innate immune repertoire shows evidence for a multi-functional domain organization that existed in the ancestor of placental mammals. BMC Mol. Biol. 2008, 9, 104. [CrossRef]

149. Münk, C.; Willemsen, A.; Bravo, I.G. An ancient history of gene duplications, fusions and losses in the evolution of APOBEC3 mutators in mammals. BMC Evol. Biol. 2012, 12, 71. [CrossRef]

150. Sheehy, A.M.; Gaddis, N.C.; Choi, J.D.; Malim, M.H. Isolation of a human gene that inhibits HIV-1 infection and is suppressed by the viral Vif protein. Nature 2002, 418, 646-650. [CrossRef]

151. Silvas, T.V.; Schiffer, C.A. APOBEC3s: DNA-editing human cytidine deaminases. Protein Sci. 2019, 28, 1552-1566. [CrossRef]

152. Vasudevan, A.A.; Smits, S.H.; Hoppner, A.; Häussinger, D.; Koenig, B.W.; Münk, C. Structural features of antiviral DNA cytidine deaminases. Biol. Chem. 2013, 394, 1357-1370. [CrossRef]

153. Xu, W.K.; Byun, H.; Dudley, J.P. The Role of APOBECs in Viral Replication. Microorganisms 2020, 8, 1899. [CrossRef]

154. Hayward, J.A.; Tachedjian, M.; Cui, J.; Cheng, A.Z.; Johnson, A.; Baker, M.L.; Harris, R.S.; Wang, L.F.; Tachedjian, G. Differential Evolution of Antiretroviral Restriction Factors in Pteropid Bats as Revealed by APOBEC3 Gene Complexity. Mol. Biol. Evol. 2018, 35, 1626-1637. [CrossRef]

155. Ito, J.; Gifford, R.J.; Sato, K. Retroviruses drive the rapid evolution of mammalian APOBEC3 genes. Proc. Natl. Acad. Sci. USA 2020, 117, 610-618. [CrossRef] [PubMed]

156. Jebb, D.; Huang, Z.; Pippel, M.; Hughes, G.M.; Lavrichenko, K.; Devanna, P.; Winkler, S.; Jermiin, L.S.; Skirmuntt, E.C.; Katzourakis, A.; et al. Six reference-quality genomes reveal evolution of bat adaptations. Nature 2020, 583, 578-584. [CrossRef]

157. Jarmuz, A.; Chester, A.; Bayliss, J.; Gisbourne, J.; Dunham, I.; Scott, J.; Navaratnam, N. An anthropoid-specific locus of orphan C to U RNA-editing enzymes on chromosome 22. Genomics 2002, 79, 285-296. [CrossRef] [PubMed]

158. Münk, C.; Beck, T.; Zielonka, J.; Hotz-Wagenblatt, A.; Chareza, S.; Battenberg, M.; Thielebein, J.; Cichutek, K.; Bravo, I.G.; O'Brien, S.J.; et al. Functions, structure, and read-through alternative splicing of feline APOBEC3 genes. Genome Biol. 2008, 9 , R48. [CrossRef]

159. Wiegand, H.L.; Doehle, B.P.; Bogerd, H.P.; Cullen, B.R. A second human antiretroviral factor, APOBEC3F, is suppressed by the HIV-1 and HIV-2 Vif proteins. EMBO J. 2004, 23, 2451-2458. [CrossRef] [PubMed]

160. Zheng, Y.H.; Irwin, D.; Kurosu, T.; Tokunaga, K.; Sata, T.; Peterlin, B.M. Human APOBEC3F is another host factor that blocks human immunodeficiency virus type 1 replication. J. Virol. 2004, 78, 6073-6076. [CrossRef] [PubMed] 
161. Hakata, Y.; Miyazawa, M. Deaminase-Independent Mode of Antiretroviral Action in Human and Mouse APOBEC3 Proteins. Microorganisms 2020, 8, 1976. [CrossRef] [PubMed]

162. Salas-Briceno, K.; Zhao, W.; Ross, S.R. Mouse APOBEC3 Restriction of Retroviruses. Viruses 2020, 12, 1217. [CrossRef] [PubMed]

163. Horn, A.V.; Klawitter, S.; Held, U.; Berger, A.; Vasudevan, A.A.; Bock, A.; Hofmann, H.; Hanschmann, K.M.; Trosemeier, J.H.; Flory, E.; et al. Human LINE-1 restriction by APOBEC3C is deaminase independent and mediated by an ORF1p interaction that affects LINE reverse transcriptase activity. Nucleic Acids Res. 2014, 42, 396-416. [CrossRef] [PubMed]

164. Koning, F.A.; Newman, E.N.; Kim, E.Y.; Kunstman, K.J.; Wolinsky, S.M.; Malim, M.H. Defining APOBEC3 expression patterns in human tissues and hematopoietic cell subsets. J. Virol. 2009, 83, 9474-9485. [CrossRef] [PubMed]

165. Mohanram, V.; Skold, A.E.; Bachle, S.M.; Pathak, S.K.; Spetz, A.L. IFN-alpha induces APOBEC3G, F, and A in immature dendritic cells and limits HIV-1 spread to CD4+ T cells. J. Immunol. 2013, 190, 3346-3353. [CrossRef] [PubMed]

166. Peng, G.; Lei, K.J.; Jin, W.; Greenwell-Wild, T.; Wahl, S.M. Induction of APOBEC3 family proteins, a defensive maneuver underlying interferon-induced anti-HIV-1 activity. J. Exp. Med. 2006, 203, 41-46. [CrossRef]

167. Refsland, E.W.; Stenglein, M.D.; Shindo, K.; Albin, J.S.; Brown, W.L.; Harris, R.S. Quantitative profiling of the full APOBEC3 mRNA repertoire in lymphocytes and tissues: Implications for HIV-1 restriction. Nucleic Acids Res. 2010, 38, 4274-4284. [CrossRef]

168. Jaguva Vasudevan, A.A.; Balakrishnan, K.; Franken, A.; Krikoni, A.; Häussinger, D.; Luedde, T.; Münk, C. Murine leukemia virus resists producer cell APOBEC3A by its Glycosylated Gag but not target cell APOBEC3A. Virology 2021, 557, 1-14. [CrossRef]

169. Hu, Y.; Knecht, K.M.; Shen, Q.; Xiong, Y. Multifaceted HIV-1 Vif interactions with human E3 ubiquitin ligase and APOBEC3s. FEBS J. 2020. [CrossRef]

170. Marin, M.; Rose, K.M.; Kozak, S.L.; Kabat, D. HIV-1 Vif protein binds the editing enzyme APOBEC3G and induces its degradation. Nat. Med. 2003, 9, 1398-1403. [CrossRef]

171. Sheehy, A.M.; Gaddis, N.C.; Malim, M.H. The antiretroviral enzyme APOBEC3G is degraded by the proteasome in response to HIV-1 Vif. Nat. Med. 2003, 9, 1404-1407. [CrossRef]

172. Yu, X.; Yu, Y.; Liu, B.; Luo, K.; Kong, W.; Mao, P.; Yu, X.F. Induction of APOBEC3G ubiquitination and degradation by an HIV-1 Vif-Cul5-SCF complex. Science 2003, 302, 1056-1060. [CrossRef]

173. Yu, Y.; Xiao, Z.; Ehrlich, E.S.; Yu, X.; Yu, X.F. Selective assembly of HIV-1 Vif-Cul5-ElonginB-ElonginC E3 ubiquitin ligase complex through a novel SOCS box and upstream cysteines. Genes Dev. 2004, 18, 2867-2872. [CrossRef]

174. Britan-Rosich, E.; Nowarski, R.; Kotler, M. Multifaceted counter-APOBEC3G mechanisms employed by HIV-1 Vif. J. Mol. Biol. 2011, 410, 1065-1076. [CrossRef]

175. Guerrero, S.; Libre, C.; Batisse, J.; Mercenne, G.; Richer, D.; Laumond, G.; Decoville, T.; Moog, C.; Marquet, R.; Paillart, J.C. Translational regulation of APOBEC3G mRNA by Vif requires its 5'UTR and contributes to restoring HIV-1 infectivity. Sci. Rep. 2016, 6, 39507. [CrossRef]

176. Kao, S.; Khan, M.A.; Miyagi, E.; Plishka, R.; Buckler-White, A.; Strebel, K. The human immunodeficiency virus type 1 Vif protein reduces intracellular expression and inhibits packaging of APOBEC3G (CEM15), a cellular inhibitor of virus infectivity. J. Virol. 2003, 77, 11398-11407. [CrossRef] [PubMed]

177. Santa-Marta, M.; da Silva, F.A.; Fonseca, A.M.; Goncalves, J. HIV-1 Vif can directly inhibit apolipoprotein B mRNA-editing enzyme catalytic polypeptide-like 3G-mediated cytidine deamination by using a single amino acid interaction and without protein degradation. J. Biol. Chem. 2005, 280, 8765-8775. [CrossRef] [PubMed]

178. Stopak, K.; de Noronha, C.; Yonemoto, W.; Greene, W.C. HIV-1 Vif blocks the antiviral activity of APOBEC3G by impairing both its translation and intracellular stability. Mol. Cell 2003, 12, 591-601. [CrossRef]

179. Kolokithas, A.; Rosenke, K.; Malik, F.; Hendrick, D.; Swanson, L.; Santiago, M.L.; Portis, J.L.; Hasenkrug, K.J.; Evans, L.H. The glycosylated Gag protein of a murine leukemia virus inhibits the antiretroviral function of APOBEC3. J. Virol. 2010, 84, 10933-10936. [CrossRef] [PubMed]

180. Renner, T.M.; Belanger, K.; Lam, C.; Gerpe, M.C.R.; McBane, J.E.; Langlois, M.A. Full-Length Glycosylated Gag of Murine Leukemia Virus Can Associate with the Viral Envelope as a Type I Integral Membrane Protein. J. Virol. 2018, 92, e01530-17. [CrossRef] [PubMed]

181. Rosales Gerpe, M.C.; Renner, T.M.; Belanger, K.; Lam, C.; Aydin, H.; Langlois, M.A. N-linked glycosylation protects gammaretroviruses against deamination by APOBEC3 proteins. J. Virol. 2015, 89, 2342-2357. [CrossRef]

182. Stavrou, S.; Nitta, T.; Kotla, S.; Ha, D.; Nagashima, K.; Rein, A.R.; Fan, H.; Ross, S.R. Murine leukemia virus glycosylated Gag blocks apolipoprotein B editing complex 3 and cytosolic sensor access to the reverse transcription complex. Proc. Natl. Acad. Sci. USA 2013, 110, 9078-9083. [CrossRef]

183. Jaguva Vasudevan, A.A.; Perkovic, M.; Bulliard, Y.; Cichutek, K.; Trono, D.; Häussinger, D.; Münk, C. Prototype foamy virus Bet impairs the dimerization and cytosolic solubility of human APOBEC3G. J. Virol. 2013, 87, 9030-9040. [CrossRef]

184. Perkovic, M.; Schmidt, S.; Marino, D.; Russell, R.A.; Stauch, B.; Hofmann, H.; Kopietz, F.; Kloke, B.P.; Zielonka, J.; Strover, H.; et al. Species-specific inhibition of APOBEC3C by the prototype foamy virus protein bet. J. Biol. Chem. 2009, 284, 5819-5826. [CrossRef]

185. Zhang, Z.; Perković, M.; Gu, Q.; Balakrishnan, K.; Sangwiman, A.; Häussinger, D.; Lindemann, D.; Münk, C. HIV-2 Vif and foamy virus Bet antagonize APOBEC3B by different mechanisms. Virology 2021, 554, 17-27. [CrossRef]

186. Lecellier, C.H.; Dunoyer, P.; Arar, K.; Lehmann-Che, J.; Eyquem, S.; Himber, C.; Saib, A.; Voinnet, O. A cellular microRNA mediates antiviral defense in human cells. Science 2005, 308, 557-560. [CrossRef] 
187. Cullen, B.R. Role and mechanism of action of the APOBEC3 family of antiretroviral resistance factors. J. Virol. 2006, 80, 1067-1076. [CrossRef] [PubMed]

188. Hahn, H.; Baunach, G.; Brautigam, S.; Mergia, A.; Neumann-Haefelin, D.; Daniel, M.D.; McClure, M.O.; Rethwilm, A. Reactivity of primate sera to foamy virus Gag and Bet proteins. J. Gen. Virol. 1994, 75, 2635-2644. [CrossRef] [PubMed]

189. Weikel, J.; Löchelt, M.; Truyen, U. Demonstration of feline foamy virus in experimentally infected cats by immunohistochemistry. J. Vet. Med. A Physiol. Pathol. Clin. Med. 2003, 50, 415-417. [CrossRef] [PubMed]

190. Cullen, B.R. Mechanism of action of regulatory proteins encoded by complex retroviruses. Microbiol. Rev. 1992, 56, 375-394. [CrossRef]

191. Löchelt, M.; Zentgraf, H.; Flügel, R.M. Construction of an infectious DNA clone of the full-length human spumaretrovirus genome and mutagenesis of the bel 1 gene. Virology 1991, 184, 43-54. [CrossRef]

192. Lecellier, C.H.; Vermeulen, W.; Bachelerie, F.; Giron, M.L.; Saib, A. Intra- and intercellular trafficking of the foamy virus auxiliary bet protein. J. Virol. 2002, 76, 3388-3394. [CrossRef]

193. Adachi, A.; Sakai, H.; Tokunaga, K.; Kawamura, M. Functional analysis of human spuma retrovirus genome. Virus Genes 1995, 11, 15-20. [CrossRef] [PubMed]

194. Baunach, G.; Maurer, B.; Hahn, H.; Kranz, M.; Rethwilm, A. Functional analysis of human foamy virus accessory reading frames. J. Virol. 1993, 67, 5411-5418. [CrossRef] [PubMed]

195. Lee, A.H.; Lee, H.Y.; Sung, Y.C. The gene expression of human foamy virus does not require a post-transcriptional transactivator. Virology 1994, 204, 409-413. [CrossRef]

196. Yu, S.F.; Linial, M.L. Analysis of the role of the bel and bet open reading frames of human foamy virus by using a new quantitative assay. J. Virol. 1993, 67, 6618-6624. [CrossRef]

197. Giron, M.L.; de The, H.; Saib, A. An evolutionarily conserved splice generates a secreted env-Bet fusion protein during human foamy virus infection. J. Virol. 1998, 72, 4906-4910. [CrossRef] [PubMed]

198. Meiering, C.D.; Linial, M.L. Reactivation of a complex retrovirus is controlled by a molecular switch and is inhibited by a viral protein. Proc. Natl. Acad. Sci. USA 2002, 99, 15130-15135. [CrossRef]

199. Saib, A.; Koken, M.H.; van der Spek, P.; Peries, J.; de The, H. Involvement of a spliced and defective human foamy virus in the establishment of chronic infection. J. Virol. 1995, 69, 5261-5268. [CrossRef] [PubMed]

200. Bock, M.; Heinkelein, M.; Lindemann, D.; Rethwilm, A. Cells expressing the human foamy virus (HFV) accessory Bet protein are resistant to productive HFV superinfection. Virology 1998, 250, 194-204. [CrossRef]

201. Bing, T.; Wu, K.; Cui, X.; Shao, P.; Zhang, Q.; Bai, X.; Tan, J.; Qiao, W. Identification and functional characterization of Bet protein as a negative regulator of BFV3026 replication. Virus Genes 2014, 48, 464-473. [CrossRef]

202. Alke, A.; Schwantes, A.; Kido, K.; Flotenmeyer, M.; Flügel, R.M.; Löchelt, M. The bet gene of feline foamy virus is required for virus replication. Virology 2001, 287, 310-320. [CrossRef] [PubMed]

203. Ledesma-Feliciano, C.; Hagen, S.; Troyer, R.; Zheng, X.; Musselman, E.; Slavkovic Lukic, D.; Franke, A.M.; Maeda, D.; Zielonka, J.; Münk, C.; et al. Replacement of feline foamy virus bet by feline immunodeficiency virus vif yields replicative virus with novel vaccine candidate potential. Retrovirology 2018, 15, 38. [CrossRef]

204. Robert, X.; Gouet, P. Deciphering key features in protein structures with the new ENDscript server. Nucleic Acids Res. 2014, 42, W320-W324. [CrossRef]

205. Callaway, E. 'It will change everything': DeepMind's AI makes gigantic leap in solving protein structures. Nature 2020, 588, 203-204. [CrossRef]

206. Mulnaes, D.; Porta, N.; Clemens, R.; Apanasenko, I.; Reiners, J.; Gremer, L.; Neudecker, P.; Smits, S.H.J.; Gohlke, H. TopModel: Template-Based Protein Structure Prediction at Low Sequence Identity Using Top-Down Consensus and Deep Neural Networks. J. Chem. Theory Comput. 2020, 16, 1953-1967. [CrossRef] [PubMed]

207. Mulnaes, D.; Koenig, F.; Gohlke, H. TopSuite Web Server: A Meta-Suite for Deep-Learning-Based Protein Structure and Quality Prediction. J. Chem. Inf. Model. 2021, 61, 548-553. [CrossRef] [PubMed]

208. Rose, A.S.; Bradley, A.R.; Valasatava, Y.; Duarte, J.M.; Prlić, A.; Rose, P.W. Web-based molecular graphics for large complexes. In Proceedings of the 21st International Conference on Web3D Technology, Anaheim, CA, USA, 22-24 July 2016 ; pp. 185-186.

209. Rose, A.S.; Hildebrand, P.W. NGL Viewer: A web application for molecular visualization. Nucleic Acids Res. 2015, 43, W576-W579. [CrossRef]

210. Roy, A.; Kucukural, A.; Zhang, Y. I-TASSER: A unified platform for automated protein structure and function prediction. Nat. Protocols 2010, 5, 725-738. [CrossRef]

211. Yang, J.; Yan, R.; Roy, A.; Xu, D.; Poisson, J.; Zhang, Y. The I-TASSER Suite: Protein structure and function prediction. Nat. Methods 2015, 12, 7-8. [CrossRef]

212. Yang, J.; Zhang, Y. I-TASSER server: New development for protein structure and function predictions. Nucleic Acids Res. 2015, 43, W174-W181. [CrossRef]

213. Schrödinger Release 2021-1: Prime; Schrödinger LLC: New York, NY, USA, 2021.

214. Bienert, S.; Waterhouse, A.; de Beer, T.A.P.; Tauriello, G.; Studer, G.; Bordoli, L.; Schwede, T. The SWISS-MODEL Repository-new features and functionality. Nucleic Acids Res. 2016, 45, D313-D319. [CrossRef] [PubMed] 
215. Waterhouse, A.; Bertoni, M.; Bienert, S.; Studer, G.; Tauriello, G.; Gumienny, R.; Heer, F.T.; de Beer, T.A.P.; Rempfer, C.; Bordoli, L.; et al. SWISS-MODEL: Homology modelling of protein structures and complexes. Nucleic Acids Res. 2018, 46, W296-W303. [CrossRef]

216. DiMaio, F.; Leaver-Fay, A.; Bradley, P.; Baker, D.; André, I. Modeling symmetric macromolecular structures in Rosetta3. PLoS ONE 2011, 6, e20450. [CrossRef] [PubMed]

217. Yang, J.; Anishchenko, I.; Park, H.; Peng, Z.; Ovchinnikov, S.; Baker, D. Improved protein structure prediction using predicted interresidue orientations. Proc. Natl. Acad. Sci. USA 2020, 117, 1496. [CrossRef] [PubMed]

218. Ovchinnikov, S.; Kamisetty, H.; Baker, D. Robust and accurate prediction of residue-residue interactions across protein interfaces using evolutionary information. eLife 2014, 3, e02030. [CrossRef]

219. Kamisetty, H.; Ovchinnikov, S.; Baker, D. Assessing the utility of coevolution-based residue-residue contact predictions in a sequence- and structure-rich era. Proc. Natl. Acad. Sci. USA 2013, 110, 15674. [CrossRef] [PubMed]

220. Balakrishnan, S.; Kamisetty, H.; Carbonell, J.G.; Lee, S.-I.; Langmead, C.J. Learning generative models for protein fold families. Proteins Struct. Funct. Bioinform. 2011, 79, 1061-1078. [CrossRef] [PubMed]

221. Altschul, S.F.; Gish, W.; Miller, W.; Myers, E.W.; Lipman, D.J. Basic local alignment search tool. J. Mol. Biol. 1990, 215, 403-410. [CrossRef]

222. Mulnaes, D.; Golchin, P.; Koenig, F.; Gohlke, H. TopDomain: Exhaustive Protein Domain Boundary Meta-Prediction Combining Multi-Source Information and Deep Learning. J. Chem. Theory Comput. (under review).

223. Mulnaes, D.; Gohlke, H. TopScore: Using Deep Neural Networks and Large Diverse Data Sets for Accurate Protein Model Quality Assessment. J. Chem. Theory Comput. 2018, 14, 6117-6126. [CrossRef]

224. Holm, L. Using Dali for Protein Structure Comparison. In Structural Bioinformatics: Methods and Protocols; Gáspári, Z., Ed.; Springer: New York, NY, USA, 2020; pp. 29-42.

225. Edelmann, F.T.; Schlundt, A.; Heym, R.G.; Jenner, A.; Niedner-Boblenz, A.; Syed, M.I.; Paillart, J.-C.; Stehle, R.; Janowski, R.; Sattler, M.; et al. Molecular architecture and dynamics of ASH1 mRNA recognition by its mRNA-transport complex. Nat. Struct. Mol. Biol. 2017, 24, 152-161. [CrossRef] [PubMed]

226. Rozbesky, D.; Robinson, R.A.; Jain, V.; Renner, M.; Malinauskas, T.; Harlos, K.; Siebold, C.; Jones, E.Y. Diversity of oligomerization in Drosophila semaphorins suggests a mechanism of functional fine-tuning. Nat. Commun. 2019, 10, 3691. [CrossRef] [PubMed]

227. Yan, Y.; Wen, Z.; Wang, X.; Huang, S.-Y. Addressing recent docking challenges: A hybrid strategy to integrate template-based and free protein-protein docking. Proteins Struct. Funct. Bioinform. 2017, 85, 497-512. [CrossRef] [PubMed]

228. Krüger, D.M.; Ignacio Garzón, J.; Chacón, P.; Gohlke, H. DrugScorePPI Knowledge-Based Potentials Used as Scoring and Objective Function in Protein-Protein Docking. PLoS ONE 2014, 9, e89466. [CrossRef]

229. Mistry, J.; Chuguransky, S.; Williams, L.; Qureshi, M.; Salazar, G.A.; Sonnhammer, E.L.L.; Tosatto, S.C.E.; Paladin, L.; Raj, S.; Richardson, L.J.; et al. Pfam: The protein families database in 2021. Nucleic Acids Res. 2021, 49, D412-D419. [CrossRef]

230. Chareza, S.; Slavkovic Lukic, D.; Liu, Y.; Rathe, A.M.; Münk, C.; Zabogli, E.; Pistello, M.; Löchelt, M. Molecular and functional interactions of cat APOBEC3 and feline foamy and immunodeficiency virus proteins: Different ways to counteract host-encoded restriction. Virology 2012, 424, 138-146. [CrossRef]

231. Zhang, Z.; Gu, Q.; Marino, D.; Lee, K.L.; Kong, I.K.; Häussinger, D.; Münk, C. Feline APOBEC3s, Barriers to Cross-Species Transmission of FIV? Viruses 2018, 10, 186. [CrossRef]

232. Huthoff, H.; Autore, F.; Gallois-Montbrun, S.; Fraternali, F.; Malim, M.H. RNA-dependent oligomerization of APOBEC3G is required for restriction of HIV-1. PLoS Pathog. 2009, 5, e1000330. [CrossRef]

233. Kreisberg, J.F.; Yonemoto, W.; Greene, W.C. Endogenous factors enhance HIV infection of tissue naive CD4 T cells by stimulating high molecular mass APOBEC3G complex formation. J. Exp. Med. 2006, 203, 865-870. [CrossRef]

234. Li, J.; Chen, Y.; Li, M.; Carpenter, M.A.; McDougle, R.M.; Luengas, E.M.; Macdonald, P.J.; Harris, R.S.; Mueller, J.D. APOBEC3 multimerization correlates with HIV-1 packaging and restriction activity in living cells. J. Mol. Biol. 2014, 426, 1296-1307. [CrossRef]

235. Jaguva Vasudevan, A.A.; Hofmann, H.; Willbold, D.; Häussinger, D.; Koenig, B.W.; Münk, C. Enhancing the Catalytic Deamination Activity of APOBEC3C Is Insufficient to Inhibit Vif-Deficient HIV-1. J. Mol. Biol. 2017, 429, 1171-1191. [CrossRef]

236. Wang, X.; Dolan, P.T.; Dang, Y.; Zheng, Y.H. Biochemical differentiation of APOBEC3F and APOBEC3G proteins associated with HIV-1 life cycle. J. Biol. Chem. 2007, 282, 1585-1594. [CrossRef] [PubMed]

237. Jaguva Vasudevan, A.A.; Balakrishnan, K.; Gertzen, C.G.W.; Borveto, F.; Zhang, Z.; Sangwiman, A.; Held, U.; Kustermann, C.; Banerjee, S.; Schumann, G.G.; et al. Loop 1 of APOBEC3C regulates its antiviral activity against HIV-1. J. Mol. Biol. 2020, 432, 6200-6227. [CrossRef]

238. Burns, M.B.; Lackey, L.; Carpenter, M.A.; Rathore, A.; Land, A.M.; Leonard, B.; Refsland, E.W.; Kotandeniya, D.; Tretyakova, N.; Nikas, J.B.; et al. APOBEC3B is an enzymatic source of mutation in breast cancer. Nature 2013, 494, 366-370. [CrossRef] [PubMed]

239. Jaguva Vasudevan, A.A.; Kreimer, U.; Schulz, W.A.; Krikoni, A.; Schumann, G.G.; Häussinger, D.; Münk, C.; Goering, W. APOBEC3B Activity Is Prevalent in Urothelial Carcinoma Cells and Only Slightly Affected by LINE-1 Expression. Front. Microbiol. 2018, 9, 2088. [CrossRef] [PubMed]

240. Lin, L.; Holmes, B.; Shen, M.W.; Kammeron, D.; Geijsen, N.; Gifford, D.K.; Sherwood, R.I. Comprehensive Mapping of Key Regulatory Networks that Drive Oncogene Expression. Cell Rep. 2020, 33, 108426. [CrossRef] 
241. Roberts, S.A.; Lawrence, M.S.; Klimczak, L.J.; Grimm, S.A.; Fargo, D.; Stojanov, P.; Kiezun, A.; Kryukov, G.V.; Carter, S.L.; Saksena, G.; et al. An APOBEC cytidine deaminase mutagenesis pattern is widespread in human cancers. Nat. Genet. 2013, 45, 970-976. [CrossRef]

242. Roelofs, P.A.; Goh, C.Y.; Chua, B.H.; Jarvis, M.C.; Stewart, T.A.; McCann, J.L.; McDougle, R.M.; Carpenter, M.A.; Martens, J.W.; Span, P.N.; et al. Characterization of the mechanism by which the RB/E2F pathway controls expression of the cancer genomic DNA deaminase APOBEC3B. Elife 2020, 9, e61287. [CrossRef]

243. Salamango, D.J.; McCann, J.L.; Demir, O.; Brown, W.L.; Amaro, R.E.; Harris, R.S. APOBEC3B Nuclear Localization Requires Two Distinct N-Terminal Domain Surfaces. J. Mol. Biol. 2018, 430, 2695-2708. [CrossRef] [PubMed] 